Utah State University

DigitalCommons@USU

$\mathrm{Bu}$

Bee Lab

9-28-1904

\title{
On Some New Genera and Species of Hymenoptera from Cape Colony and Transvaal
}

Peter Cameron

Follow this and additional works at: https://digitalcommons.usu.edu/bee_lab_bu

Part of the Entomology Commons

\section{Recommended Citation}

Cameron, Peter, "On Some New Genera and Species of Hymenoptera from Cape Colony and Transvaal" (1904). Bu. Paper 201.

https://digitalcommons.usu.edu/bee_lab_bu/201

This Conference Paper is brought to you for free and open access by the Bee Lab at DigitalCommons@USU. It has been accepted for inclusion in Bu by an authorized administrator of DigitalCommons@USU. For more information, please contact digitalcommons@usu.edu.

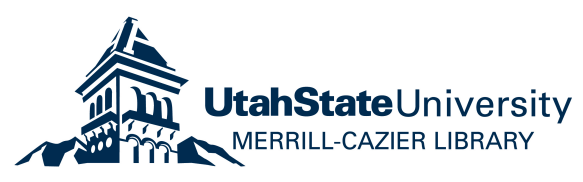


ON SOME NEW GENERA AND SPECIES OF HYMENOPTERA FROM CAPE COLONY AND TRANSTAAL.

By P. Cameron.

(Read September 28, 1904.)

This paper is based on species collected for me by the Rer. J. A. O'Neil at Dunbrody, at Pearston and Stellenbosch by Prof. Robert Broom; on species in the Collection of the Albany Museum, Grahamstown, collected by Mrs. G. White, Mrs. Pringle, and Misses Daly and Sole in the neighbourhood of Grahamstown, for the loan of which I am indebted to Dr. S. Schönland; and a fer species from the Transwaal in my own Collection.

\section{FAMILI ICHNEUMONID在. HEMITELINI. \\ CENOACLAX, gen. nov:}

Metanotum with one transverse curved keel, its spiracles small, circular. Mesonotum trilobate, transversely striated. Scutellum roundly conrex, its sides on the basal half keeled. Clypeus separated from the face, its apex rounded and narrowed. Mandibles bi-dentate; the sub-apical tooth small, the apical long and sharply pointed. Mesosternum furrowed laterally on the basal half. Wings without an areolet, the transrerse cubital nerrure very short, the cubitus and radius almost touching where it unites them; the recurrent nervure is received beyond it. Transverse median nerrure received shortly behind the transverse basal. Transverse median nerrure in hind wings broken below the middle; the radius obsolete from near the base; the cubitus entirely so. Legs slender, the claws sparsely combed. First abdominal segment sessile; becoming gradually widened from the base to the apex; longer than it is wide in the middle; the spiracles placed near the apical third. The basal three segments are strongly closely longitudinally striated; 
shortly behind the middle of the first and second and in the middle of the third is a wide deep transverse furrow; the third and fourth segments laterally have the apical half roundly curved in the centre, the apex distinctly projecting; there are seren segments.

Antennæ 25-jointed; the first joint of flagellum not quite so long as the second. Eyes large; the ocelli widely separated from themby the same distance they are from each other; ther reach to the top of the vertex. Face and clypeus densely clothed with longish white pubescence.

In Ashmead's system this genus would come in near Allocota, Foer. The deep transverse furrows on the abdomen remind one of the Braconid genus, Iphiaulax.

\section{C.exoaulax striates, sp. nov.}

Dark rufous, the head, breast, and legs black; antennæ black, dark rufous at the base; front legs dark testaceous, the hind tibix with a clear white band on the base; the calcaria pale; wings clear braline, the nerrures and stigma black; the apical abdominal segments white. $q$.

Length $6 \mathrm{~mm}$. ; terebra $1 \mathrm{~mm}$.

Cape Colony. Grahamstown, April.

Head rugosely punctured; sparsely haired on the front and vertex, the rest thickly covered with long clear white pubescence; from the ocelli stout striæ run obliquely backwards to the eyes. Hind ocelli separated from each other by about the same distance they are from the eves. Thorax covered with white pubescence; the mesonotum transversely striated; a narrow longitudinal furrow in the centre of the middle lobe. Scutellum roundly convex, coarsely rugosely punctured. Base of metanotum rugose; the apical slope slightly but distinctly hollowed, obscurely transversely striated; its edges keeled. Pleuræ closely rugosely punctured; the apex of the prostoutly striated. Basal two segments of the abdomen stoutly, longitudinally striated; the third and fourth rugosely punctured, irregularly striated; the apical segments smooth. Palpi long, white. Base or mandibles rufous. Legs covered with a white pile. The long spur of the hind tibix does not reach to the middle of the metatarsus: it is as long as the second joint.

\section{LIENELLA. gen. nor.}

Yetanotum with fifteen areæ in three rows; the base obliquely depressed in the middle. Wings without an areolet; the transverse cubital nerrure short, not much longer than broad; the recurrent nervure about three times its length from it. Transverse median nervure interstitial. Transverse median nervure in hind wings broken distinctly below the middle; the radius and cubitus faint. Forewings spotted. Antenno at least 18-jointed (the apical joints are broken off); pilose; the second joint of flagellum longer than the third. Eyes large; malar space small. Hind ocelli clearly separated from the eyes; they are separated from them by a less distance than they are from each other. Occiput margined. First abdominal segment long (as long as the following two segments united), slender, not much dilated at the apex; the spiracles near the middle; the middle of the post-petiole keeled: the second and third segments closely, strongly longitudinally striated. Sternal furrow wide, deep. Legs long, slender, the tarsi closely spinose below; claws simple. Temples broad, obliquely narrowed. Occiput margined.

The affinities of this species are with C'enoaulax here described. It is easily separated by the areolated metanotum, longer and more slender abdominal petiole, and by the absence of transrerse furrow on the basal segments.

\section{LIENELLA Nigriceps, sp. nor.}

Rufous, antennæ, except the scape and basal joints of flagellum, head, breast, median segment, except the base of the pleuræ, and the base and apex of the abdomen black. Legs rufous, the anterior paler, more yellow in tint. Wings clear hraline, the nerrures and stigma black; there is a brown cloud which extends from shortly behind the base of the radius to shortly beyond the middle of the radial cellule and posteriorly to the discoidal nerrure. $\sigma$.

Length $6 \mathrm{~mm}$.

Cape Colony. Dunbrody, February 17th.

Front closely, roundly striated; a square forea in the middle below. Tertex closely, finely obliquely striated. Mesonotum closely striated; obliquely at the base, the rest transversely; apex of middle deeply longitudinally furrowed. Scutellar depression wide, deep. Scutellum rugosely punctured. The base of the first central area smooth, its apex closely transversely striated, the second punctured, the outer rugose; the central outer reticulated; the others with a few irregular keels. Pro- and meso-pleuræ punctured and irregularly striated; the meta- closely, rugosely punctured. Post-petiole with some tine longitudinal strix; the second and third segments closely, strongly longitudinally striated. Hind coxæ and femora punctured, thickly corered with white hair, 


\section{PIMPLINI.}

COSMIOPIMPLA, gen. nor.

Transverse median nerrure in hind wings broken distinctly below the middle. Areolet oblique, of equal width, longer than broad, shortly appendiculated at the first transverse cubital nerrure; discocubital nervure broken by a stump of a nerrure, sharply angled. Apex of clypeus obliquely depressed, slightly rounded. Last joint of antennx nearly as long as the preceding two united. Fore claws with a stout tooth at the base. Abdominal segments broader than long, coarsely, closely punctured, and with transverse furrows. Wings large, yellowish-hyaline, with fuscous clonds. Eyes emarginate within. Oripositor elongate, straight.

In Ashmead's arrangement (Bull. U.S. Nat. Mus., xxiii., 57) this genus would come in near l'impla and Notopimpla, but these may be known by the transverse median nerrure in hind wings being broken above the middle, in addition to the other differences.

\section{COSMIOPINIPLA FERREGINEA, sp. nor.}

Ferruginous, flacrellum of antennæ, apical third of hind tibiæ and the hind tarsi black; wings yellowish-hyaline, a broad fuscous cloud immediately beyond the transverse median and transrerse basal nerrures, narrowed slightly in front and extending from the costa to the opposite side, a slightly narrower cloud extending from the base of the stigma to the areolet, and backwards to the apex of the wing, thence proceeding along the apex, upwards to the costa ; hind wings fuscous, yellowish-hyaline to near the middle and haring a yellowish braline cloud in the centre of the apical fuscous part, wide in front, gradually narrowed behind; the stigma and nerrures in the vellow part luteous. Head and thorax smooth and shining; the base and sides of metanotum sparsely, distinctly punctured; the basal four segments of abdomen closely, strongly punctured; the others smooth; the furrows wide and deep. $q$.

Length $12 \mathrm{~mm}$.; terebra $8 \mathrm{~mm}$.

Cape Colony. Brak Kloof.

\section{Gex. PIMPLA, Fab. sec. Ashm.}

\section{Pimpla limbata, Tosq.}

This species is in the Collection from Jannerill (Miss Lippan). It cannot be referred to Pimpla as now defined. It might be referred to Cosmiopimpla if it were not that the apex of the clypeus is transverse and slightly depressed, and the fore claws not toothed at the base.

\section{Tribe LISSONOTINI.}

\section{Gex. Lissonota, Gray.}

Lissoxota interstitialis, sp. nor.

Black, the abdomen red, the apices of the basal three segments narrowly yellow; the eye orbits all round, the face, clypeus, mandibles, and palpi yellow, the face with a black line down the centre, becoming wider towards the apex and extending round the top of the clypeus. On the centre of the mesonotum are tro broad lines, which are triangularly dilated on the outer side at the base, the apical two-thirds of the propleuræ above, the lower side more narrowly yellow, the two lines being united by a broader oblique line which runs from the base of the upper; a curved irregular line in the centre of the mesopleuræ extending from near the base to the apex, a short line under the hind wings, an elongated ovoid mark on the centre of the metapleurre, the sides and apex of scutellum, the apical line projecting slightly beyond the lateral ones; and a curred line on the apex of the metanotum, with a conical projection at its base, yellow. Four front legs yellow, tinged with fulrous behind; the hinder red, the coxæ and trochanters yellow, the former broadly black in the middle above; the four posterior tarsi fuscous. Pedicle of the areolet nearly twice the length of the lower branches. $q$.

Length $12 \mathrm{~mm}$.; terebra $7 \mathrm{~mm}$.

Cape Colony. Dunbrody, December.

Head closely and distinctly punctured; the clypeus sparsely punctured above. The thorax is much more coarsely punctured all over and covered with a white pile. The first abdominal segment is shining, sparsely and minutely punctured on the apical half; the others are finely and closely punctured; the apical pilose; the third and fourth are black along the lower part of the sides. The recurrent nerrure is interstitial with the second transrerse cubital.

\section{Tries NOTOTRACHINI.}

\author{
Gex. NOTOTRACHYS, Marshall. \\ Nototrachys flavomaculates, sp. nor.
}

Rufous, the face, clypeus, mandibles, palpi, eve orbits, prothorax, two lines, dilated at the base, on the mesonotum, scutellums, apical slope of metanotum, the :nesopleuræe except above the middle, the apex of metapleuræ broadly and the part below the hind wings, pale 
yellow; legs rufous, the four front tibix paler; the back of the second and following abdominal segments blackish above; antennal scape rufous, the flagellum blackish. Wings hyaline, the stigma and nervures black. $q$.

Length $10 \mathrm{~mm}$.; abdomen $7 \mathrm{~mm}$.; oripositor $3 \mathrm{~mm}$.

Head smooth, shining; the front kecled down the centre, transversely, closely striated. Mesonotum strongly, irregularly transversely striated, except on the sides at the apex where it is punctured. Scutellum reticulated. Metanotum at the base with a transverse keel, which curves towards the post-scutellum in the middle ; this part is almost smooth; the rest of the median segment is closely, strongly reticulated. Propleuræ stoutly, obliquely striated at the base. Basal half of mesopleuræ above longitudinally striated; the apical smooth; the lower punctured-reticulated. Metapleuræ coarsely reticulated. There is a curved keel in front of the middle coxa and another between it and the posterior. The wings are short, about half the length of the body.

Cape Colony. Dunbrody.

\section{Tribe OPHIONINI.}

\section{Gex. LIMNERIUM, Ashm. (LIMNERIA, Auct.)}

LiMNERICM STELLENBosChENSE, sp. nov.

Black, shining; antemnal scape and legs rufous; all the trochanters, the four front cosæ and the middle of the hind tibiæ pale vellow; the hind coxie black, a band near the base of the hind tibiæ, a broader one on their apex and the apices of the hind tarsal joints fuscous, the rest of the hind tarsal joints pale; the apices of the basal three abdominal segments rufo-testaceous, as are also the sides of the third and fourth. Wings hyaline, the stigma fuscous, the nervures darker. $q$.

Length $5 \mathrm{~mm}$.; terebra $1 \mathrm{~mm}$.

Cape Colony. Stellenbosch.

Head shagreened, the face not so strongly as the front, and more shining. Palpi yellow. Thorax minutely, closely punctured, the median segment more strongly and less shining than the rest. There are no closed areæ on the metanotum; from near the centre of the base two keels run obliquely to the middle of the segment, which bears silvery-white pubescence. The basal branch of the areolet is as long as the pedicle; the apical is distinctly longer than either; the areolet distinctly projects below; the basal branch of the projection being clearly longer than the apical.

$$
\text { Gex. ASPHR.tGIS, Foer. }
$$

Asphragis? Rufipes, sp. nov.

Head pale bright yellow, the front and vertex broadly in the centre and the occiput black; the thorax red, the pro- and meta-notum black; abdomen black, the third and fourth segments for the greater part dull rufous above; legs coloured like the thorax, the tarsi darker in tint; wings clear hyaline, the stigma dark fuscous. $\sigma$.

Length $6 \mathrm{~mm}$.

Cape Colony. Stellenbosch

Scape of antennæ dull red below; basal joints of flagellum elon. gate; the first slightly longer than the second. Head closely and strongly punctured; the punctures on the front and rertex more distinctly separated than they are on the face; the clypeus, except above, smooth. Mandibles pale yellow, their teeth black, the part behind them rufous. Palpi testaceous. Thorax closely and strongly punctured; scutellar depression smooth and shining; the metanotum more coarsely punctured than the mesonotum; there is one stout transverse keel on the apical slope ; the part on either side of this is irregularly striated. Tibiæ sparsely, the tarsi more thickly spinose; legs long and slender; the fore tarsi longer than the tibiæ. The transverse median nervure is received shortly beyond the transrerse basal; the apical nerrures in the hind wings are faint; the transverse cubital nervure is broken below the middle.

This may not be an Asphragis, which has the claws closely pectinated, whereas here the pectinations are few and widely separated.

\section{GEx. CHAROPS, Holmgren.}

\section{Charops spinitarsis, sp. nor.}

Black; the four anterior legs bright yeliow, the hinder dark red, their tibiæ and tarsi darker coloured than the femora; all the coxæ black; the basal joint of hind femora black, the apical yellow; the abdomen rufous, blackish above; wings clear hyaline, the nerrures and stigma blackish. $q$.

\section{Length $10 \mathrm{~mm}$.}

Cape Colony. Stellenbosch.

Head and thorax covered thickly with white pubescence, the pubescence longest on the face and outer eye orbits. Head and thoras closely and distinctly punctured. Propleuræ strongly striated, the strix distinctly separated, except abore; the hollowed middle and the apex of the mesopleuræ are less strongly striated; the upper part of the metapleuræ is irregularly obliquely striated, 
especially above, where there is a keel down the middle. On the basal half of the metanotum are two longitudinal keels which converge slightly below; on either side of them, at the base, is a large area, wider than long, obliquely narrowed below, the outer part being the larger; the apex of the segment is closely irregularly reticulated. Tibiæ and tarsi spinose. Apex of mandibles and palpi yellowish testaceous. Abdominal petiole curred, as long as the following two segments united, its apex distinctly dilated

\section{StB-FAMILY TRYPHONIN正.}

\section{Gex. ExOCHUS, Gravenh.}

\section{Exoches? Fuscipiloses, sp. nov.}

Black; the head and thorax thickly corered with fuscous pubescence; the face below the antennx brownish; the greater part of the antennæ testaceous; wings hyaline, the stigma and nerrures fuscous; legs bright red. Shining, impunctate. Posterior median area slightly obliquely narrowed at the base; the petiolar area widest at the base. $\delta$.

Length $4 \mathrm{~mm}$.

Cape Colony. Stellenbosch.

This species is not quite a typical Exochus. I therefore give some structural details. On the metanotum are five areæ; the posterior median is narrowed at the base and confluent with the petiolar; the apical slope is surrounded by keels; the spiracular area confluent with the area dentipara. Spiracles on petiole placed close to the base; petiole with two longitudinal keels on the basal half; there is no keel on the second abdominal segment. Malar space large. The small spiracles touch the lower keel of the spiracular area.

Taking this species as typical of Exochus that genus may be separated from Plesioexochus, described here, as follows :-

Metathoracic spiracles elongate, larce; first joint of flagellum much longer than the second: apex of metanotum with an $\begin{array}{lllllllllllll}\text { oblique slope } & . & \ldots & . . & . & . & . & . . & . . & . & . . & . & \text { I'lesioerochus. }\end{array}$

Metathoracic spiracles small, oval; first joint of flacellum as long as second; apex of metanotum with a rounded slope .. Frochus.

\section{PLESIOEXOCHUS, gen. nor.}

Wings without an areolet; transverse basal nervure received distinctly beyond transverse median; transierse median nervure in
Some New Genera and Specics of Hymenoptera.

hind wings broken far below the middle. Temples narrow, obliquely narrowed; vertex not separated from occiput by a keel. Median segment with, in all, eight areæ; the apex has a sharply oblique slope and is surrounded by stout keels which form one large area. First abdominal segment about twice longer than it is wide at the apex, towards which it becomes gradually wider; in the centre are two longitudinal keels; the spiracles are placed before the middle; second abdominal segments without a keel. Hind tibiæ with two spurs. First joint of the flagellum as long as the following two united. Metanotal spiracles elongate, about three times longer than wide.

This genus comes close to Exochus, which may be known from it by the first abdominal segment not having keels, by the temples being well developed, and by the transverse median nervure being interstitial, not widely separated from the basal as in the present genus, these differences being in addition to those just noted.

\section{Plesioexochus rufipes, sp. nov.}

Black, shining, the head and upper part of thorax thickly covered with longish fuscous pubescence; the legs bright red, covered with a white pile; wings hyaline, the nervures and stigma fuscous; the front below the antennæ brown; the greater part of the antennæ fuscous below. $\delta$

Length $6 \mathrm{~mm}$.

Cape Colony. Stellenbosch.

Face and clypeus closely, strongly puncturer; the apex of the clypeus smooth and shining. Mandibles obscurely tinged with testaceous. Palpi bright testaceous. Propleuræ shining, bare, deeply depressed in the middle. Hind calcaria stout, the longer reaching beyond the middle of the metatarsus. Apices of tarsal joints minutely spined.

\section{FAHIL BRACONIDA.}

\section{Gex. BRACON, Fab. sec. Ashm.}

Bracos whitei, sp. nor.

Red; the antenux, front and vertex, a mark, slightly longer than broad and rounded below, in the top of the face above and the mesonotum, except the sutures behind, black; wings dark fuscous, at large cloud behind the transverse median nerrure and reaching from 
the costa to the apex of the latter; the middle region of the radial cellule largely, the first cubital cellule entirely, the base and apex of the second, the apical cloud the larger and wider part in front, the black cloud having an irregular apex, longest behind the base of the third cellule, the cloud widest in front; the first discoidal cellule except for a large triangular cloud at the base, a small, less clearly. defined, cloud at the apex of the third, the base of the first posterior cellule broadly, and of the second posterior more obscurely, yellowishhyaline; the base of the stigma luteous, the rest of it and the nervures black. Apical joint of the four hinder tarsi black. $q$.

Length $23 \mathrm{~mm}$. ; terebra $40 \mathrm{~mm}$.

Cape Colony. Brak Kloof.

Head and thorax smooth and shining, the face with a yellowish hue, rugose, finely, closely striated on the sides below. Third abscissa of radius longer than the basal two united; the recurrent nelvure interstitial. Abdomen with the basal six segments closely rugosely punctured; the area on the second segment triangular, not reaching to the middle of the segment, closely longitudinally striated and surrounded by a less closely, more strongly, more obliquely striated border; there is a narrow, closely longitudinally striated line down the centre of the third, fourth, and fifth segments; there is a large smooth spot on the basal half of the third segment; the transverse furrows on the others are smooth and shining on the sides.

This species, in its strongly punctured abdomen, more resembles Iphiaulax than Eracon, but it wants the oblique and transverse furrows of that genus.

\section{Bracon stellexboschesisis, sp. nor.}

Luteous, the antennæ, the ocellar region, the occiput broadly in the centre, apex of mesonotum, middle of metanotum and the mesosternum black; wings byaline, the nerrures and stigma fuscous. $q$. Length slightly over $2 \mathrm{~mm}$.; terebra $1 \mathrm{~mm}$.

Hab. Cape Colony. Stellenbosch.

Head and thorax smooth; the centre of metanotum irregularly; rather strongly, obliquely striated. The second, third, and fourth abdominal segments aciculated; metapleurx covered with long white pubescence; the suturiform articulation closely striated. Palpi pale testaceous. Mandibles testaceous. Third abscissa of radius as long as the basal two united. The second abdominal segment is obscurely, closely striated; it has no central keel nor basal area. Ventral surface pale yellow.

$$
\text { Gex. IPHIAULAX, Foer. }
$$

IPHIALLAX ORNATICOLLIS, sp. nor.

Black; a mark on the malar space, a line on the upper part of the propleuræ, narrow at the base, becoming gradually wider towards the apex and an oblique mark on the lower side at the apex, orangeyellow; wings clear yellowish hyaline to the apex of the stigma, fuscous beyond; the stigma orange-yellow, black at its base and apex; apical abscissa of radius somewhat longer than the basal two united. Palpi black. $q$.

Length $13 \mathrm{~mm}$.; terebra $2 \mathrm{~mm}$.

Cape Colony. Dunbrody.

Antennæ densely microscopical pilose; the scape short, compressed, longer below than its width above, laterally becoming gradually wider towards the apex. Face opaque, closely minutely punctured and covered with long black hair; front and vertex smooth and shining. Temples wide, as long as the antennal scape, not obliquely narrowed, rounded behind. Abdomen as long as the head and thorax; smooth; the middle of the first segment keeled longitudinally, the keel not reaching the apex; the area on second segment triangular, slightly longer than its width at the base; its lateral furrow roundly curved inwardly; an oblique keel on the sides of the third; the furrows are smooth. Hind femora compressed laterally below. The cloud in the hind wings commences shortly beyond the middle.

\section{PARASPINARIA, gen. nor.}

Abdomen with seven segments; closely rugosely reticulated, the apical two minutely denticulate; the last bluntly rounded; the suturiform articulation not cleft at the sides; the area on the second segment triangular, reaching to the apex. Mesonotum trilobate, the furrows reaching to the scutellum. Metonotum widely furrowed in the centre. Head cubital, the temples well developed, not obliquely narrowed; the occiput slightly roundly incised. Clypeus convex, roundly narrowed behind, its sides bordered by depressions. Transverse median nervure received beyond the transverse basal; the recurrent nervure received in apex of first cubital cellule; the abscissæ of radius become successively longer, the last roundly curved upwards. Hind wings as in Exothecus except that the costal cellule is much more narrowed at the apex, the nerrures almost touching there. Antennal scape short, about three times longer than broad; the first joint of flagellum slightly longer than broad. 
The stigma is large; the radius issues from shortly behind its middle. Legs of moderate size; the fore claws bifid, the basal tooth the shorter; the other claws simple. Calcaria not reaching to the middle of metatarsus. Malar space large. Eyes parallel, not converging. A stout keel between the antennæ. The $\delta$ has only six abdominal segments; the apical two are not toothed; the last is broadly rounded at the apex. It is more pilose than the $q$.

The relationship of this genus appears to be with Spinaria. That genus has the abdomen differently formed, and with only five segments, the spines, too, being much more conspicuous; the head is smaller, with the temples obliquely narrowed; the antennæ much longer and thinner; the eyes incised on the inner side; the prothorax is much more elongate and narrowed and often spined; and the abdominal segments longitudinally striated. Szepligeti (Termés Fuz. xxiv. 45) describes a genus, Mesobracon, from the Congo, which appears to be allied to Paraspinaria, but the apical abdominal segments are not spined. As this genus probably extends to Cape Colony I give the full description of it as given by Szepligeti: Head transverse, radial cellule long, not reaching to the apex of the wing, abdomen closely granular-rugose. Seren segments visible, the second with a cental area. At p. 45 l.c. it is stated that the abdomen is not spined in the $q$, the only sex described.

\section{Parispixalia V-olixata, sp. nor.}

Black; the apex of the first abdominal segment, the edges of the area on the second segment, forming a $\mathbf{V}$-shaped mark and a line down the centre of the third, fourth, and fifth segments, brown; wings yellowish byaline to the apex of the stigma, beyond that fuscous, except for a small hyaline cloud on either side of the second transrerse cubital nervure, the base of the radial cellule being yellowish hyaline; the apical fourth of the hind wings fuscous. Nandibles rufo-testaceous. $q$ and $\sigma$.

Length $14 \mathrm{~mm}$. ; terebra $5 \mathrm{~mm}$.

Cape Colony. Brak Kloof.

Head smooth and shining, the face indistinctly keeled. An oblique forea or depression on the sides of the clypeus, its apex with an indistinctly crenulated furrow, the edge sharply turned up. Metanotum widely and deeply furrowed in the centre, its sides oblique. First abdominal segment coarsely irregularly reticulated in the centre; the others closely rugosely punctured, the centre irregularly reticulated. The area on the second segment reaches to the apes of the segment and forms a triangle; the transverse furrows are narrow, deep and striated; the first is not cleft at the sides; there are four furrows of equal width and depth and all closely striated. The third abscissa of the radius is curred and is also long as the second cubital abscissa; the recurrent nerrure is received near the apex of the first cubital cellule

The middle lobe of the mesonotum is clearly separated, especially at the apex where the furrows are broad. Antennal scape short. The sides of the seventh abdominal segnient armed with four short teeth; the centre at the apex roundly incised; the sixth segment denticulate all round the apex, the teeth longer and more distinct at the sides, where, on the outer side, they are more widely separated. The apical segments are more distinctly reticulated than the basal. The third segment has a smooth, shining space on the sides near the base; the fourth to sixth with smooth, lateral depressions.

The $\delta$ wants the teeth on the apical abdominal segments, of which there are only six ; the last is broady rounded at the apex:

\section{Gex. METEORUS, Haliday.}

Meteorus capensis, sp. nov.

Black, shining; the coxæ and trochanters testaceous, the femora darker testaceous, the tibiæ and tarsi blackish; wings hyaline, iridescent, the stigma black, the nervures pale. $\delta$.

Length 4-5 $\mathrm{mm}$.

Cape Colony. Stellenbosch.

Antennæ much longer than the body, fuscous at the base, covered with a close microscopic pile. Head shining, aciculated; malar space with some irregular striæ. Clypeus more strongly aciculated than the face; its sides above bordered by a deep depression, Mandibles brownish; palpi blackish. Middle lobe of mesonotum aciculated, opaque, pilose; the lateral bare and shining; the furrows closely, irregularly rugose. Upper part of mesopleuræ rugose, the oblique depression on the lower half irregularly striated. Median segment coarsely, irregularly rugose, the metanotum almost reticulated; on the upper edge of the pleuræ are two curved keels with some strix between them. Petiole closely, distinctly longitudinally striated; the other segments smooth and shining. Legs pilose; the pubescence longer and white on the femora, shorter, darker, and closer on the tibiæ and tarsi. Wing nerrures pale; the second cubital cellule is distinctly narrowed in front; the transverse median nervure is received shortly beyond the basal; the recurrent shortly in front of the transverse cubital; 
both the transverse cubital nervures are bullated on the lower side next to the cubitus.

The petiole is brouder than usual and has distinct tracheal rrooves; the second cubital cellule is more narrowed in front than it is in most of the species.

\section{CHALCII)ID 玉.}

\author{
GEN. DIRRHINUS, Dalm.
}

DIRRHINUS RLFICORNIS, sp. nov.

Black, the antenux and four front legs rufous; the hind tarsi pale testaceous: wings hyaline, suffused with fulrous in the midale. $\delta$.

Length $3 \mathrm{~mm}$.

Cape Colony. Stellenbosch; Grahamstown.

Head and thorax covered with silvery pubescence. Frontal process longer than the eyes, gradually narrowed into a sharp point; the lower side longer than the upper and with a distinct point; the lower side longer than the upper and with a dightly narmargin, grooved a the apex; flat, with the sides raised into a stout rowed towards the apex; flat, with the sides raised into a stout border or keel; the head is strongly and closely punctured, the punctures running into reticulations on the process. Clypeus projecting, smooth, bare, shining; its sides stoutly keeled. Pro- and meso-thorax strongly punctured, the scutellum roundly bordered behind; the metapleuræ closely reticulated. Metanotum with stout keels forming areæ; in the centre are two keels which, on the basal half, curve roundly outwardly; the apical half at the top projects obliquely wutwards, the rest being only slightly oblique; inside, at the end of the narrowed basal part, is a narrower keel, which curves round the apex is raised and behind is a rounded keel : at the base in the centre is a stout keel, narrowed towards the apex and reaching near to the apex of the narrowed basal part of the area; on the sides is a long area ; its outer keel is straight, oblique, the inner curves roundly to the outer keel, with the apex oblique, straight. The abdominal petiole is as broad as long; in the centre are two stout keels; bordered by three narrower ones; the base of the second segment is tinely, closely striated. Apex of abdomen trilobate, the middle lobe broader and more rounded than the lateral, which becomes gradually narrowed to a bluntly rounded point.

The sides of the metanotum project into a blunt, oblique tooth, this projecting part being hollowed and striated in the centre.
Some Neu Gencra and Species of Hymenoptera.

Assuming that Mr. Kirby's figure of I). excaratus, Dal. (a widelyspread African species), is correct, the species here described may be readily known by the central area on the metanotum being much larger and longer, reaching to the apex, whereas in excacatus the central area only reaches to the middle and is followed by two larger ones which extend to the sides.

RHYNCHOCHALCIS, gen. nor.

Antennæ inserted over the mouth, 10-jointed, the last longer than the preceding two united. Malar space longer than the length of the eyes. Apex of scutellum with two rounded lobes. Sides of metanotum above with a stout, turned up obliquely, tooth. Ovipositor stout, fully one-third longer than the abdomen, the segments enclosing it reaching shortly beyond the middle. Hind femora greatly thickened, untonthed, pilose below.

The antennæ are short and stout, the scape does not reach to the ocelli; its apex is dilated; the frontal depression at the sides and abore clearly keeled, the keel enclosing the front ocellus. Below the eyes the head becomes distinctly, obliquely narrowed, forming a snout. There is a large rounded keel between the antennæ. Malar space keeled on inner side.

In Dr. Ashmead's arrangement (Mem. Carnegie Museum, i., 256) this genus comes nearest to Hippota, with which it cannot be confounded in either sex. The very long ovipositor reminds one of Megachalcis and Megacolus, which, however, do not belong to the Halticcllini.

RHINCHOCHALCIS NIGER, sp. nov.

Black, thickly covered with silvery pubescence, the wings fuscohyaline, the nervures and stigma black. $q$.

Length $8 \mathrm{~mm}$. ; terebra $4-5 \mathrm{~mm}$.

Cape Colony. Stellenbosch.

Head opaque, alutaceous; the vertex and outer orbits punctured, the latter more strongly above than below; the orbits and the malar space thickly covered with long silvery pubescence. Clypeus shining, sparsely punctured below and more depressed there than above. A smooth keel runs down from the centre of the eyes to the mandibles. Pro- and meso-thorax strongly punctured, the base of mesopleuræe smooth and shining, the rest opaque, rugosely, closely punctured and densely covered with long fuscous pubescence. The sides and apex of scutellum distinctly margined, the apex in the middle transverse, the sides obliquely narrowed. In the centre of the metanotum are two longitudinal keels; at the base is a row of round forer, 
bordered by a stout curved keel; the sides are bordered by a stout keel, inside of which are some irregular transverse keels; there are also two or three broken longitudinal keels. Abdomen closely punc. tured, the base of the segments smooth and shining. The basal part of the oripositor is closely punctured, the apical smooth. The four front tarsi are covered with testaceous pubescence beneath; their calcarea testaceous; the hind tibiæ keeled on the sides below.

\section{ENCYRTID无.}

\section{EUPELMINE.}

\section{MESOCOMYS, gen. nor.}

Antennæ 13-jointed, thickened towards the apical joint, which is long, thick, becomes gradually narrowed, and is hollowed in the middle below; the flagellum sparsely pilose, the second joint four times longer than thick; they are placed not far from the mouth and widely separated from the eyes. Front only slightly excarated in the centre; the rertex roundly, broadly convex. Eyes large, oval; the malar space large; the eyes slightly converge above. Parapsidal furrows narrow, distinct; the centre of the mesonotum raised, broad, rounded behind and separated from the scutellum by an irregulariy raised space. Scutellum large, longer than wide, rounded and sligbt!y narrowed at the apex; at its base are two large, deep forex, widest at the base, rounded at the apex. Base of metanotum triforeate, the middle fovea the larger. Pleura not excarated. Abdominal segments not incised. Fore femora dilated, narrowed at the base and apex, flattened in front; the four hinder femora more slender and longer, as are also their tibiæ; the basal joint of middle tarsi greatly swollen; the middle tibiæ grooved behind, their spurs much thicker than the anterior or posterior, longer, reaching to the middle of metatarsus. The sub-marginal rein long, reaching to the middle, its apical third curved downwards, thickened and in front thickly margined with longish hair; marginal vein short, not onefourth of the length of the sub-marginal : radius thick, curved, cleft at the apex, the upper fork short and curved, the lower straight and oblique. Clypeus furrowed in the centre, the furrow widest at the apex. Occiput transverse in the middle, the sides obliquely rounded.

I am not quite certain as to the exact systematic position of this genus. It should be readily known by the densely pilose, curved apex of the sub-marginal rein, by the cleft apex of stigmal branch, by the two large deep forex at the base of scutellum and by the three large forea at the base of the metanotum.

\section{Mesocomys relchricers, sp. nov.}

Dark purple, mixed with blue and brassy tints; the head dark purple on the sides of the rertex, the centre blue; the front fiery coppery red, the clypeus green; antenna black, the scape rufotestaceous; legs black, the tarsi and the fore femora and tarsi in front testaceous; wings hyaline, the middle clouded, except at the base of the marginal vein, where there is a hyaline cloud of equal width. $q$.

Length $3 \mathrm{~mm}$.

Head closely, distinctly punctured, the vertex less strongly than the rest; sparsely pilose. Thorax smooth, the pleuræ very minutely, indistinctly punctured; the furrow on the pronotum testaceous. Ovipositor shortly projecting, testaceous. There is a narrow testaceous band on the base of the middle tibia.

Cape Colony. Grahamstown; Brak Kloof.

\section{FOSSORES.}

\section{SCOLIID王.}

Grx. DIELIS, Sauss.,

Dielis ERIONOTUS, sp. nov.

Black, thickly covered with long, white woolly pubescence, the clypeus, except for a large triangular mark in the centre, labrum, base of mandibles, a line on the apex of the fore femora and the four anterior tibiæ behind, yellow; the calcaria and tarsal spines white: wings hyaline, the stigma and nerrures black. $\delta$.

Length $18 \mathrm{~mm}$.

Cape Colony: Dunbrody.

The hair on the head and thorax is longer and denser than in most males, it hiding the sculpture; it is sparser on the clypeus which is smooth, impunctate, this appearing to be also the case with the thorax, so far as can be made out through the dense hair covering. The black on the abdomen has a bluish tinge; on the second segment the band is dilated in the middle and still more so laterally; on the third it is narrower but is more distinctly dilated in the middle; in both the lateral expansion extends beyond the middle: the bands on the other segments are narrow and are fringed with golden hair. 


\section{SPHEGID $Æ$.}

Gex. PALARUS, Latr.

Palarts curvilineatus, sp. nov.

Length $11 \mathrm{~mm}$. $ठ$.

Cape Colony. Steynsburg, January.

Similar in the colouration of the head and thorax to P. lineatifrons, but the vellow lines on the abdomen are paler, wanting the rufous tinge; they are much narrower, the basal being also distinctly, roundly curved; the metanotal fovea is larger, it reaching to the base of the segment; it is broader there, is deeper and wants the keels, the alar nerrures and stigma are black, not testaceous; the first transverse cubital nerrure has not the upper part obliquely bent, and the pygidium is not closely, regularly striated.

There is a smooth line below the lower ocellus; below it is a narrow keel; the larger yellow keel has not a forea; the lower ocellus almost round, with a curve above the middle. Eves distinctly converging above, separated there by almost the length of the third and fourth antennal joints. Clypeus shining, only sparsely, weakly punctured. Metanotum closely, strongly punctured, except round the fovea, where there is a broad, rounded, smooth border; the fovea is transverse at the base and half the width it is at the apex. The basal third of the mesonotum is broadly depressed in the middle. The second ventral segment becomes gradually dilated from the base to the apex; the basal two-thirds of the pygidium stoutly keeled in the centre, the sides with some broken, oblique, irregular keels, forming almost reticulations; the apex not depressed. The basal spines are broad, project obliquely outwardly, and are roundly curred on the inner and outer sides; the base with some large punctures, the apex smooth. The basal two yellow abdominal lines are entire, the apical four interrupted in the middle. The cheeks are thickly covered with long silvery-white hair; the front and vertex bear longish white hair: the clypeus is almost bare. Mesonotum and scutellum shining, distinctly, but not closely punctured, the latter smooth in the centre. Median segment, except round the forea, closely rugosely punctured. The sellow line on the post-scutellum is interrupted in the middle; there are no yellow marks on the scutellum. Legs black; the under side of the four front femora, the tibix, and tarsi are yellow; the tibial and tarsal spmes are almost white. Tegula brownish, with a large yellow spot on the hase. The first and second transrerse cubital nerrures unite at the top; the upper two-thirds of the first and third transverse cubital nervures are obliquely bent; the first recurrent nervure is received shortly beyond the transverse cubital ; the lower part of the apical abscissa of the radius is oblique, the upper straight; the outer branch is shorter than the lower part.

\section{Palares lineatifrons, sp. nor.}

Black; the inner eye orbits broadly below, narrowly above, antennal keel, a mark, roundly dilated above, in the centre of the face below, clypeus, base of mandibles broadly, a line on the hinder edge of the pronotum, the base of the propleuræ-the mark roundly incised at the apex-a curved mark on the apex above, tegulæx, a mark in front of them, reaching to the lower edge of the mesonotum, a small oblique mark on the base of the mesopleuræe above, a large mark on the base extending from the top to below the midale, broadest abore, rounded below, the base of the metapleuræ, the line irregularly wared on the apex, an irregular mark behind the spiracles, a large mark on the apex, its lower half irregularly dilated back. wards, two lines on the base of the scutellum and the post-scutellum, pale vellow; the first abdominal segment rufous-rellow, with a somewhat triangular mark in the centre at the apex; the second to fourth segments broadly from behind the middle, the lines dilated at the sides, a narrower line not dilated laterally and almost separated in the middle, the basal two ventral segments, except broadly in the middle, the apices of the others narrowly and irregularly, yellow with a rufous tint. Legs yellow, the greater part of the coxæ, the trochanters, the base of femora all round, their upper part broadly, and the tibiæ behind. black. Wings clear hyaline, the nerrures testaceous. $q$.

Length $12-13 \mathrm{~mm}$.

Cape Colony. Somerset East.

Pygidium stoutly, regularly longitudinally striated to near the narrowed apex, which is hollowed. Eres distinctly converging abore, separated there by fully the length of the third and fourth antennal joints. Frontal keel stout, long, rounded above, narrowed towards the apex. Anterior ocellus large, wider than long. widely separated from the posterior. Vertex closely and strongly punctured, the front not so closely nor so strongly, the clypeus sparsely punctured. Mandibles rufous in the centre. The whole head is thickly corered with longish white hair. Pro- and meso-thoras closely and strongly punctured, shining and thickly covered with white pubescence. Scutellum sparsely punctured at the base and 
apex. Median segment, except at the base, closely punctured; in the centre of the base is a large, somewhat pyriform fovea, the narrow end at the base. Second cubital cellule almost sessile, the nervures uniting at the top. Tibix spinose, the hinder almost serrate behind, the fore tarsi fringed with long stiff spines on the outer side; the hinder hare also long stout spines as well as short ones.

The front below the ocelli is roundly raised; immediately behind the dilated part it is furrowed; there is a longish, distinct ovate forea below the top of the frontal keel; the basal half of the metanotal forea is not so much depressed as the apical ; it has a stout keel in the centre and its sides are also keeled.

\section{Gex. PIAGETIA, Rits.,}

\section{Piagetia striata. sp. nov.}

Black, the basal four joints of the antenna, the clypeus except in the middle at the base, mandibles except the teeth, fore legs, the middle in front and the tegulæ, brownish castaneous; wings hyaline, a not very distinct cloud in the basal half of the radial cellule, in the apex of the first cubital, the second and third cubitals, and along both sides of the recurrent nervures. $q$.

Length $9 \mathrm{~mm}$.

Cape Colony. Dunbrody, February.

Hind femora without a tooth. Basal part of metanotum closely, uniformly, and distinctly transversely striated; the apical slope smooth, thickly covered with silvery pubescence; there is a narrow longitudinal keel on the basal half. Lower part of front and clypeus thickly covered with silvery pubescence. Apex of clypeus almost transverse, the middle with a slight shallow incision. Antennal scape as long as the pedicle and first joint of flagellum; the pedicle about three times longer than wide. Head opaque, wider than the thorax; a shallow furrow in the centre of the front and a wider, deeper one on either side of its apical half. Eyes slightly but distinctly converging above. Pleure alutaceous, the apex of the metairregularly obliquely striated. Tubercles castaneous, fringed behind with silvery pubescence. First abdominal segment becoming gradually wider towards the apex; if anything longer than the second; the penultimate broadly castaneous on the apical half; the prgidium rufo-testaceous, shining, bare, strongly but not rery closely punctured, the apical half of hypopygium similarly coloured.

The tibiz and tarsi are sparsely spined; the spines long and rufous; the spines on the fore tarsi are slender, as long as the apical joint, and apparently few in number. Mandibles on lower side, behind the incision, broad, transverse. Malar space obsolete. Fore ocelli separated from the posterior three times the distance these are from each other. Median segment clearly longer than it is wide at the base, narrowed towards the apex. There is no depression or furrow on the vertex behind the ocelli.

Allied to P. kohlii, Brauns.

\section{Gex. CERCERIS, Latr.,}

Cerceris holcoNota, sp. nor.

Black; clypeus, the inner orbits to the base of antennæ, the spot obliquely narrowed above, cheeks, a conical spot--the rounded part above-below the antennal keel, the basal half of mandibles, a spot on either side of pronotum, an almost interrupted line on postscutellum, a line, narrowed in the middle on the apex of the third abdominal segment and one of equal width on the apex of the fifth, pale yellow. Legs bright red, the hind coxæ black, the tibiæ yellow on the outer side. Antennal flagellum fulvous, darker above. Wings hyaline, the apical half suffused with smoky tints; the costa and stigma dark testaceous, the nerrures black. $q$.

Length $11 \mathrm{~mm}$.

Cape Colony. Dunbrody.

Metanotal area smooth, shining, deeply furrowed in the centre: the apical slope also deeply furrowed. Clypeus flat, its apex broad, transrerse, depressed, black. Third joint of antennæ slightly shorter than the first and longer than the fourth. Hinder ocelli separated from each other by about the same distance as they are from the eves. Front and vertex strongly and closely, the face and clypeus more sparsely punctured. Front with a keel in the centre. Proand meso-notum strongly but not closely punctured; the latter broadly depressed in the centre of the basal half, the pleuræe more coarsely, closely, rugosely punctured. Abdomen strongly punctured; the pygidium opaque, granular, the base with some irregular punctures; more narrowed towards the base than to the apex: incision in epipygium reaching to the middle; the penultimate segment broadly raised in the middle, rugose, projecting laterally at the apex and densely corered with white pubescence. The third ventral segment marked with white, narrowly in the middle, broadly laterally.

Allied to C'. nigrifrons, Sm. 
Cerceris nobilitata, sp. nov.

Black; the face, clypeus, the lower half of the inner eve orbits, the base of mandibles broadly, greater part of antennal scape, basal half of tegula (the hinder rufous), a large mark, rounded laterally on the base of second segment in the centre, a band on the apex of the third, narrowed in the middle, extending to the base on the sides, and a broad mark on the apical half of the fifth and the sides of the third rentral segment broadly, yellow; the first and the sides of the second segment rufous; legs red; the outer side of the tibiæ and the base of the tarsi whitish yellow; the inner side of the hind tibix and the apical joints of the hind tarsi fuscous; wings hraline, the apex smoky; the stigma and nerrures black. $q$.

Length $11 \mathrm{~mm}$.

Duubrody. Cape Colony.

Front and vertex closely and strongly punctured, the former with a distinct keel. Face and clypeus less closely punctured; the apex of the latter broadly rounded. Hind ocelli separated from each other by a distinctly less distance than they are from the eyes. Thorax strongly, the pleuræ more coarsely, closely rugosely punctured. Metanotal area smooth and shining, indistinctly furrowed in the middle. First abdominal segment sparsely, indistinctly punc. tured; the others closely and strongly punctured; pygidium opaque, narrowed towards the base and apex, opaque, granular, coarsely at the base, finely at the apex, which is rounded; epipygium with two curved keels on the apex. The flagellum of antenna brownish, darker above; the scape for the greater part yellow; the third joint distinctly, but not much, longer than the fourth.

\section{Cerceris spinicaldata, sp. nor.}

Black: the clypeus except at the apex, face, the inner orbits broadly half-way to the ocelli, basal half of mandibles, under side of scape, outer half of tegulæ, the greater part of the four front femora, the four front tibiz and tarsi and the outer side of the hind tibix posteriorly, clear yellow. Wings hraline, the apex slightly smoky; the stigma and nervures black. $q$.

Length nearly $10 \mathrm{~mm}$.

Cape Colony. Pearston.

Metanotal area closely aciculated; a narrow crenulated furrow down the centre; the bordering furrows are also crenulated. Front and rertex rugosely punctured; a narrow furrow on the centre of the former; the antennal keel large, black, yellow above. Face and clypeus strongly, but not so closely punctured as the front; the apex of clypeus transverse, black; the sides rounded. Mandibles yellow; black at the apex. Hind ocelli separated from the eyes by the same distance as they are from each other. Thorax closely and strongly punctured, the upper parts less closely than the sides. Abdomen strongly punctured; the pygidium closely, irregularly longitudinally. reticulated, except at the apex, which is almost transverse; the epipygium ending in two stout, slightly curred piceous spines, which extend backwards to near the middle of the segments as keels.

\section{Cerceris albigena, sp. nov.}

Black; iace, inner orbits broadly to the middle of the eyes, basal half of mandibles, tegulæ, two lines on scutellum, a broad mark on the base of the second abdominal segment, rounded laterally and narrowed at the base in the middle, the apex and sides of the third segment, a narrow interrupted line on the apex of the fourth, a shorter broader one of equal width on the fifth, and a small spot on the sides, whitish-yellow. Legs red, the outer side of the tibia white, the inner side of the hinder tibix and the hind tarsi infuscated. Wings hyaline, slightly smoky, the nerrures and stigma black. 9 .

Length $9 \mathrm{~mm}$.

Cape Colony. Pearston.

Metanotal area smooth, shining; a narrow furrow in the centre, ending in a depression at the apex. Front and vertex closely and distinctly punctured. Hind ocelli separated from each other by a slightly less distance than they are from the eres; antennal keel large, plate-like, obliquely narrowed at the base and apex and continued abore as a narrow keel. Face and clypeus sparsely punctured, flat, the cheeks covered with white hair. Apex of clypeus black, depressed in the middle, transverse, the sides ending in short. bluntly rounded teeth; the sides broadly, roundly incised to near the outer edge. Pronotum rather strongly punctured, broadly depressed in the middle; mesonotum more sparsely punctured and furrowed in the middle at the base, the scutellum still more sparsely punctured. Metanotum regularly punctured. the punctures clearly separated; the apex broadly depressed. Proplemre irregularly punctured, more strongly above; mesopleura strongly and regularly punctured: the metapleuræ aciculated. Abdomen strongly punctured : the first segment thick, about one-fourth longer than thick: its apex narrowly rufous. Pygidium punctured, except at the apex, narrowed roundly at the base, becoming gradually narrowed towards the apex from the basal fourth; the apex bluntly rounded and not balf the width of the base ; the apical fourth of epipygium roundly incised. The third segment is largely white below. 
Cenceris vakilineata, sp. nov.

Black: the face, clypeus, the lower inner orbits broadly-the top narrowed and more broadly on the inner side-a mark behind the top of the eyes; a broad, irregular line on the apex of the pronotum, two large marks on the base of the scutellum, dilated on the inner side and more narrowly and longly on the outer at the apex, the post-scutellum, a large, oval mark on the sides of the median segment, a large, irregular mark on the base of the mesopleuræe, extending on to the mesosternum, which it covers entirely, and the apices of the six basal abdominal segments broadly, pale vellow, the base of the third and fourth segments broadly red. Legs bright vellow; the hind femora, apex of tibix broadly and the hind tarsi tinged with rufous. Antenno brownish, the flagellum blackish above, the scape yellow below. Wings hyaline, the apex smoky: the nervures and stigma black. $\delta$.

Length 8-9 $\mathrm{mm}$.

Cape Colony. Dunbrody.

Front and vertex rugosely punctured; the face and clypeus more sparsely punctured. Apex of clypeus broadly trilobate, the midnle lobe broader and longer than the lateral; all their apices rounded, lateral fringe white. Pro- and mesonotum punctured, but not closely, the centre of the latter smooth and with a narrow furrow at the base; the scutellum is more sparsely punctured, the postscutellum smooth. Metanotal area smooth, bordered by a row of punctures; the centre of apical slope hollowed, smooth. Pleuræ strongly, but not closely, punctured, the apex of the meso- with a broad striated band. Abdomen strongly punctured, the second, third, and fourth segments depressed at the base. Pygidium slightly narrowed towards the apex, which is slightly rufous; the punctures are few and widely separated; apex of epiprgium transverse; apices of basal four rentral segments vellow ; the middle segments densely pilose.

\section{Cerceris lakglida, sp. not.}

Black; the clypeus, a small conical mark above its middle, a large mark on the inner eye orbits, roundly narrowed above and below, a small mark broader than long below this, a mark broader than long on either side of the pronotum, tegulæ, an interrupted line on the post-scutellum, a line on the apex of the second abdominal segment, narrowed, almost interrupted in the middle, a broader one, only slightly narrowed on the third, a short mark on the sides of the fourth, and the sixth with a large mark, narrowed laterally, pale yellow; the first abdominal segment red. with a large black mark, rounded and narrowed at the apex, on the basal three-fourths. Legs black: the fore femora broadly below, a mark on the middle near the apex, the apex of the posterior, the greater part of the four front tibiæ and the outer side of the posterior pale yellow, the four front tarsi fulvous. Wing hialine, the apex infuscated, the nervures and stigma black. Flagellum of antennæ for the greater part fulvous. $\delta$.

Length $7 \mathrm{~mm}$.

Cape Colony. Dunbrody, July.

Vertex and upper part of front closely and strongly punctured; the lower part of the front aciculated; the face and clypeus as strongly, but not so closely punctured and corered with silvery pubescence. Clypeus long, obliquely narrowed from above the middle to the apex, which is sharp-pointed. Antennal keel large. Mandibles rufous, black at the point. Thorax strongly and deeply punctured; the median segment more strongly than the rest; the mesonotum with two depressions. Metanotal area smooth, shining, not furrowed in the centre. Abdomen strongly, closely and deeply punctured; pygidium of equal width and bearing some scattered punctures; the epipygium with a short, broad, rounded incision at the apex. The third joint of antennæ is, if anything, shorter than the fourth.

Cerceris orsativentris, sp. nor.

Black; the second and following segments of the abdomen ferruginous; the sides above and the base below of the fourth, fifth and sixth segments pale yellow; all the coxie, the basal half of the first and the whole of the second and third femora black, the four front trochanters rufous, the posterior black; antenmæ black, the basal three joints entirely and the fourth and fifth below ferruginous; wings uniformly fuscons-violaccous, the stigma and nervures black. Apical half of clypeus, a broad mark on the lower half of the inner orbits, roundly narrowed above and a mark below it, broader than long. Mandibles black, the basal half yellowish. $q$.

Length 13 mim.

Cape Colony. Dunbrody.

Clypeus large, projecting, the apex transrerse, the sides straight, not narrowed towards the apex; sparsely punctured; the front and vertex strongly and closely punctured. Mesonotum and scutellum strongly punctured. Metanotum coarsely rugose; the area coarsely, transversely striated. Pleuræ coarsely rugose, the base of metapleurix with a broad striated band. First abdominal segment coarsely punctured, the others smooth and shining; pygidium large, very slightly 
and gradually narrowed towards the apex, which is not transverse, being slightly curved inwardly; the punctuation is close and forms almost reticulations: the incision on epipygium not reaching to the middle, broad, rounded at the base.

Apparently closely related to ('. bicolor. Sm., from Gambia.

\section{Cerceris oneili, sp. nov.}

Black; the head, except the ocellar region and the centre of the front broadly, the hinder edge of the pronotum, tegulæ, the scutellums and two irregular marks on. the metanotum, rufous, antennæe rufous, the second and following joints of flagellum black above; abdomen lemon-yellow, the pygidial area rufous, black at the apex; legs lemon-yellow, the tibiæ and tarsi tinged with rufous; wings hyaline, the apex smoky, the costa and stigma fulvous, the nervures darker. $q$ and $\delta$

Length $17-18 \mathrm{~mm}$.

Cape Colony. Dunbrody.

Metanotal area shining, sparsely punctured, furrowed down the centre, the apex finely, closely transversely striated. Clypeus shining, roundly convex above, the apex flatter, more depressed, the lower edge depressed, transverse; the sides thickly covered with silvery depressed pubescence. Front and vertex closely and strongly punctured; antennal keel stout. Thorax closely and strongly punctured, the mesopleuræ closely rugose; its apex with a striated belt, the striæ distinctly separated and curved; the base of metapleuræ more finely and closely striated, the striæ becoming longer below: Abdomen strongly punctured; pygidial area longish, narrowed at the base and apex, the sides roundly curved outwardly, the base rugosely punctured, the middle obscurely punctured, the apex almost smooth; the extreme apex depressed, slightly curved inwardly ; the outer edges of the segment have a stout curved keel, rounded at the base, straight and oblique at the apex.

The male has the face, clypeus, mandibles, outer orbits on inner side, the sides of front, a mark in its centre, bifurcating round the ocelli, lemon-yellow; the scape and under side of flagellum lemonyellow. the upper side of latter rufous; the apex of hinder tibiæ black. Face and clypeus strongly punctured, the latter more strongly than the rest; its centre at the apex transverse. Pygidial area strongly, but not closely punctured, except at the apex, which is slightly rounded; epipygium almost transverse, with a transverse furrow not far from the apex. The last joint of the antennæ is as long as the preceding two united, is roundly incised below, the apex above slightly, below more broadly obliquely truncated. Ventral surface thickly covered with longish sivery pubescence. The basal slope of the first abdominal segment broadly in the centre, its apex and that of the second and third are narrowly black; the ventral segments are tinged with rufous. The clypeal fringe is pale golden; tegulæ yellow; the head and thorax are more thickly covered with white hair than in the female.

The third antennal joint in the male is as long as the scape, in the female it and the second are as long as it together; in the male the hinder ocelli are separated from each other by a slightly greater distance than they are from the eyes, in the female by a less distance.

Col. C. T. Bingham informs me that there is a male of this species in the British Museum from Damaraland.

\section{Cerceris melanospila, sp. nov.}

Rufous; the front from shortly behind the ocelli, the face below and on either side of the keel, the clypeal and facial sutures, the lower third of the outer orbits, the thorax except the apex of pronotum, tegulæ, tubercles, and the scutellums, the basal slope of first abdominal segment, a line in its centre reaching to the forea, a triangular mark on the base of the second segment in the centre, the base of the third, fourth and fifth segments narrowly, a line in the centre of the third, the fourth except for a square ntark on the sides at the apex, a large mark on the fifth roundly narrowed to the apex, not reaching to the apex of the segment and the ventral segments, broadly, irregularly, black. Wings hyaline, tinged with fulvous, the apex smoky; the stigma and nervures fulvous. $q$.

Length $17 \mathrm{~mm}$.

Cape Colony. Dunbrody, February; Brak Kloof; Grahamstown.

Antennat rufous; the third joint shorter than the scape and about one-fourth longer than the fourth. Clypeus roundly convex, distinctly. projecting beyond the cheeks, the apex roundly narrowed to the middle, which is transverse, with a slight depression in the centre. Front and vertex closely, distinctly punctured; the ocelli separated from the eyes by double the distance they are from each other. The upper two-thirds of the antennal keel distinctly margined, pale yellow. Pro- and meso-notum with scutellums closely rugose; the metanotum more coar'sely rugose, its area at the base obliquely, at the apex transversely striated. Mesopleura rugose, the pro- and 
metapleuræ irregularly striated. First abdominal segment sparsely and strongly, the second and third weakly punctured; pygidium smooth, the apical half black and clearly narrowed, its apex bluntly rounded; epipygium with the apical third incised; this, with the sides, are thickly covered with long stiff fulvous hair.

The male is coloured like the female except that the clypeus, face, and inner eye orbits to near the ocelli are yellow; that the abdomina segments are only slightly marked with black and that the apical joints of the antennæ are black. Apex of clypeus shortly bluntly tridentate, the middle tooth the shorter; the sides fringed with fulvous, stiff pubescence. Pygidium of equal width throughout, finely aciculated, sparsely punctured, its apex transverse, as is also the apex of epipygium.

\section{Cerceris africana, sp. nov}

Black, the abdomen from near the apex of the first segment, the legs except the hind coxæ, antennæ, clypeus, cheeks, the inner orbits from shortly above the antennæ broadly, the mark obliquely narrowed above, the lower two-thirds of the outer orbits, the line dilated obliquely backwards above, and the tegulæ rufous; the mandibles yellowish, black at the apex; wings hyaline, the apex from the end of the radius and of the third transverse cubital nervure smoky ; the nervures and stigma fulvous. $q$.

Length $14 \mathrm{~mm}$.

Cape Colony. Dunbrody.

Metanotal area closely and strongly punctured, more closely and not quite so strongly as the rest of the segment. Head and thorax thickly covered with long white pubescence. Third joint of antennæ shorter than the scape and about one-fourth longer than the following. Hinder ocelli separated from each other by a slightly, but distinctly, less distance than they are from the eyes. Clypeus roundly convex, coarsely aciculated, the apical half with longish, clearly separated punctures; its apex in the middle projecting broadly, rounded. Thorax closely and strongly punctured, the scutellum more shining and less closely punctured. First abdominal segment thickly covered with long white hair, black, the apex in the middle narrowly, the sides more broadly rufous; it is strongly, the other segnients more closely and less strongly punctured. Pygidium coarsely, irregularly wrinkled, except at the apex; it is slightly narrowed towards the base; apex of epipygium with an incision which is slightly longer than it is wide at the apex.
There is an obscure rufous line on the sides of the pronotum, an obscure rufous streak runs from the ocelli to the antennal keel, which is yellowish, bordered by rufous. The depressed base of the second and third segments black; the second segment may be broadly black at the base and the fifth narrowly; the antennæ may have the apical joints black abore.

\section{Cerceris pearstonensis, sp. not.}

Black, a broad line, roundly narrowed above and below, on the centre of the inner eye orbits, antennal keel, a line on the outer side of the pronotum, tegulæ, post-scutellum, the third abdominal segment except for a broad curved black band in the centre of the base and a broad, irregular band on the apical half of the fifth, yellow; the first segment and the second, except for a broad curred mark on its apex, red; legs black; the greater part of the fore femora and the four front tarsi rufous; all the tibiæ white on the outer side. Flagellum of antennæ for the greater part brownish. Wings hyaline, the apex smoky. $q$.

Length $9 \mathrm{~mm}$.

Cape Colony. Pearston.

Third antennal joint shorter than the scape and about one-quarter longer than the fourth. Front and vertex closely and strongly punctured. Face and clypeus thickly covered with silvery pubescence; the face and base of clypeus sparsely punctured; the apex of clypeus obliquely incised; the sides of the incision straight, forming a sharp angle in the centre and sharply projecting below, the lower edges forming sharp teeth; the lateral edges roundly; broadly incised, the apical roundly projecting. Mandibles vellowish at the base, reddish in the centre, black at the apex. Pro- and meso-notum distinctly punctured, the punctures clearly separated; the scutellum more sparsely punctured; pleuræ closely, coarsely rugosely punctured. Metanotal area longer than its width at the base, smooth; a row of deep punctures down the centre, the punctures close to each other and wider than long. Pygidium slightly narrowed towards the base and apex; slightly, irregularly, obliquely striated; its apex oblique, bordered by a rounded keel above; apex of epipygium with a rounded incision, not extending to the middle.

The amount of red on the second abdominal segment raries, it may be present on the extreme base, or the segment may be entirely red. Comes near, apparently, to $C$. albifrons, Sm., of which the male only has been described very imperfectly. 
Cerceris viricincti. sp. not:

Black: the face, clypeus, a band on the apex of the third and fourth abdominal segments, narrowest in the middle and the whole of the fifth, pale yellow; the first segment and a mark on the side of the second at the base, rufous. Antennæ rufous, darker above. Legs rufous, the four front tibiæ pale yellow on the inner side, the posterior broadly above; hind tarsi blackish. Wings fuscous, violaceous, the nervures and stigma black. $q$.

Length 11-12 $\mathrm{mm}$.

Cape Colony. Dunbrody ; Pearston.

Third joint of antennæ not much longer than the fourth. Front and rertex closely and strongly punctured, the face and clypeus more sparsely and less strongly. Apex of clypeus broad, transverse ; the face and clypeus corered with silvery pubescence. Hind ocelli separated from each other by a less distance than they are from the eyes. Thorax strongly punctured; the punctures large and clearly separated. Metanotal area smooth, raised, furrowed down the middle. Abdomen strongly punctured; the pygidium on the basal balf covered closely with broken, irregular, longitudinal striæ; the apical irregularly, longitudinally, striated and rufous; the incision on epipygium about three times longer than wide, of equal width and rounded at the base.

\section{Cerceris ruficauda, sp. nov.}

Black, the inner orbits broadly from the base of the antennæ, antennal keel, clypeus, cheeks, a spot, rounded at the base, transverse at the apex, in the centre of the first abdominal segment, a minute one on the apex of the second, a broad band, roundly narrowed in the centre, on the apex of the third, the centre of the fifth broadly and the third ventral segment broadly, yellow. Tegulæ and legs bright red, the hind coxæ black, their cosæ yellow. Antennæ black, their basal five or six joints red. Pygidium red, broadly black at the base. Wings hyaline, the radial and cubital cellules smokyviolaceous; stigma and nerrures black. $q$.

Length $7 \mathrm{~mm}$.

Cape Colony. Stellenbosch; Brak Kloof.

The third antennal joint is as long as the scape and about onefourth longer than the fourth. Front and vertex closely and strongly punctured. Hind ocelli separated from each other by a slightly less distance than they are from the eyes. Face and clypeus strongly, but not closely punctured; the apex of the latter broadly rounded; black, mandibles red, blact at the apex. Thorax strougly punctured, the upper part with the punctures larger and more widely separated. Metanotal area hollowed in the centre, the sides stoutly, irregularly, obliquely striated. Pygidium strongly, deeply punctured, of equal width throughout, the apex roundly incised, the sides forming teeth. Epipygium not incised down the middle.

\section{Cerceris whiteana, sp. nov.}

Length $11 \mathrm{~mm}$. $\quad$.

Cape Colony. Brak Kloof, June.

Very similar to $C$. holconota; may be known by the metanotal area not being furrowed, by the metanotum being neither so closely nor so strongly punctured, by the mesonotum and scutellum being much more weakly and sparsely punctured, by the apex of the clypeus not projecting so much, it being consequently not much longer than its width at the apex, while in holconotd it is distinctly. longer than its width at the apex, which is not quite transrerse as in holconota, but slightly roundly, broadly projecting in the middle with the sides tuberculate; the band on the third abdominal segment is narrow in the middle, broad at the sides where it extends to the base of the segment; there is a thin line on the centre of the fourth segment and a shorter, thicker one on the fifth; there are no marks on the pronotum and a narrow line on the scutellum; there is no distinct mark above the face; tegulæ red; under side of flagellum brownish, as is also the under side of the scape; there is no distinct keel on the front. In holconota the mesonotum is distinctly depressed in the centre, which is not the case here. The colouration, other than in the points noted, is the same.

\section{Cerceris nigrifrons, Sm.}

Specimens from Brak Kloof agree fairly well with Smith's colouration description. The species is rariable in colouration; the two yellow marks on the face mentioned by Smith may be absent ; the legs vary in the amount of black on them; the abdominal petiole may be for the greater part black. As usual no mention is made by Smith of the sculpture of the metanotal area and of the proridal area; the former is strongly striated, the striæ being stout and clearly separated; the lateral is of equal width, transterse at the apex and strongly and deeply punctured. The epipygium is almost transverse at the apex; the penultimate segment is produced laterally at the apex into sharp teeth. Apex of clypeus broadly rounded; the lateral fringe golden. The female I bave not seen. nor had Smith. 
Gex. DASYPROCTUS, Lep.

DasYproctus schöNLANDI, sp. nor.

Black; the greater part of the antennal scape, an interrupted band on the pronotum, an irregular roundish mark on the sides of the scutellum at the base, two irregular lines, widest on the outer side, behind the middle of the second abdominal segment and a broad line, narrowed laterally, on the basal half of the fifth segment, yellow; the four front femora except at the base, their tibiæ and tarsi, the apex of the hind femora and the hind tibiæ on the inner side and the hind tarsi, rufous, largely suffused with black. Wings hyaline, the apex of the radial cellule smoky, the nerrures and stigma black. $q$.

Length $8 \mathrm{~mm}$.

Cape Colony. Grahamstorn, Norember.

Front and vertex opaque, the former with shallow punctures which become stronger below: antennal depression bordered abore by a narrow, but distinct keel, below which it is smooth and shining. Face and clypeus covered with silvery pulsescence; finely rugose: the clypeus ends in two stout, widely separated teeth. Mandibles rufous, yellow at the base abore, the apex black. Mesonotum and scutellum bare, opaque; in the middle is a distinct furrow which reaches from the base to near the middle; there is a shorter, indistinct one on either side of the middle; the apex at the scutellar depression irregularly longitudinally striated; the apex of the scutellum bordered by a deep, irregularly striated furrow. Postscutellum closely rugose, irregularly, closely striated. Median segment finely rugose, irrerularly, obliquely striated, the striæ more distinct and widely separated at the base ; the segment is short, its apex widely and deeply furrowed. Pro- and meso-pleuræ opaque, with a few scattered punctures. Metapleurææ shining, thickly covered with a silky pile, obscurely, closely, obliquely striated; the apex on the lower part bordered by a stout keel, behind the lower half of which is a deep, oval fovea or depression. The abdominal petiole is as long as the following three segments united, its apical third distinctly dilated. The inner spur of the hind tibire is broad, gradually dilated towards the middle above, i.c., narrowed towards the base and apex, pallid yellow, as long as the metatarsus; the hind tibire have a few longish pale spines; the legs covered with a silvery pile.

$$
\text { GEx. OXYBELUS, Lati. }
$$

OXY'BeLe's SPINIFERES, sp. nor.

Black: the under side of the antennal scape, the hind edge of the pronotum to the tubercles, two large marks on the base of the scutellum, extending to shortly beyond the middle, two large marks on the first abdominal segment extending from the basal slope to the apex and narrowed on the inner side, a broad band on the apex of the second, narrowed and almost interrupted in the centre, and narrower lines on the following three segments, yellow. Scutellar plate large, twice longer than wide, its apex bilobate, the lobes rounded and slightly narrowed at the apex; the basal half black, the apical yellow, suffused with rufous, the centre keeled, the sides with some oblique keels. The basal half of the scutellum is deeply furrowed in the centre, the edges of the furrow bordered; its sides keeled, roundly curved, ending in a sharp point, the whole forming a broad lobe rounded and margined on the inner side; in the centre is a keel which projects into a spine at the apex. On the centre of the metanotum are two keels, which unite at the apex; the basal half of the area thus formed is irregularly, widely reticulated; the apex is smooth and hollowed; the sides are margined, the basal half bears some irregular oblique keels. Pleuræ strongly, closely punctured. The hair on the thorax is thick, white, tinged with fulvous. Back of abdomen strongly, closely punctured; the base of the segments with smooth, narrow transverse furrows. Pygidium not much narrowed towards the apex, which is smooth, almost transverse. From the apices of the sides of the dorsal five segments projects a stout, oblique, longish, slightly curred white spine. Legs yellow; all the coxæ and trochanters, the four front femora broadly above and the hind femora, except at the apex, clear yellow. Wings above and the costa and nerrures black. Flagellum brownish below. Lower part of front, face, and clypeus thickly corered with silvery. pubescence. Mandibles yellow, rufous at the apex.

Length $6 \mathrm{~mm}$. $\&$.

Cape Colony. Stellenbosch.

\section{Gex. SCELIPHRON, Klug. (PELOPOEUS, Anct.).}

\section{SCELIPHRON? LEPTOGASTER, sp. nor.}

Black; the apex of petiole, the penultimate abdominal segment except the basal half abore and the last segment testaceous; the four front legs rufo-testaceous, the fore tarsi paler; the posterior tibiæ tinged behind with testaceous; hind spurs testaceous; head and thorax thickly covered with silvery pubescence; wings hyaline, the nerrures blackish. Tarsal spines white. $\delta$.

Length $17 \mathrm{~mm}$.

Cape Colony. Dunbrody, February.

This species may form the type of a new genus or sub-genus. I 
know, unfortunately, only the male. It is more slenderly built than usual; the petiole is as long as the rest of the abdomen together; it is 2-jointed, with the apex dilated; it is straight, not curved; the last segment is sharp-pointed and is as long as the preceding two united. Scutellum furrowed in the middle. Temples roundly narrowed. Tarsi sparsely spined; the tibia with rery few spines; fore tarsi more than twice the length of the tibiæ, the basal two joints being together as long as the tibix: the middle tarsi are nearly as long, but their tibiæ are longer. The second cubital cellule longer than the third, more so in front than behind. Claws simple. Pronotum short, wider than long. Head aciculated, the sides of the vertex in front, and the front strongly but not closely punctured; the clypeus with fine scattered punctures; its apex almost depressed. Pro- and meso-notum shining; the former finely and sparsely, the latter more closely and strongly punctured. Scutellum punctured like the mesonotum except in the depressed middle. Post-scutellum not depressed, strongly punctured. Metanotum rugose, widely furrowed down the middle of the basal region before the apical slope; the furrow transrersely striated. Propleuræ smooth, shining, bare; the meso- and metapleuræ punctured, more strongly below than above; densely pilose. Abdomen smooth; the petiole longer than the head and thorax united. The second cubital cellule in front is about one-fourth longer than behind, equal in length with the third; the first recurrent nervure is received near the apex of the basal fourth of the cellule; the second nearer the apex. The apical nervures in. hind wings are faint, almost obsolete; accessory nervure appendiculated.

This species shows an approach to the Neotropical genus Podium.

\section{CEROPALID $Æ . *$}

\section{Gex. ANOPLIUS, Ashm.}

Axoplits whiteanus, sp. nor.

Black; the antennæ and legs rufous; the under side of the scape yellow; the rest black; the coxæ, trochanters, and base of femora broadly black; the tarsi paler coloured; the apices of the joints black, testaceous behind the black apex; wings yellowish hyaline, smoky from shortly beyond the third transverse cubital and the recurrent nervures. 3

Length $11 \mathrm{~mm}$.

Cape Colony. Brak Kloof.

$$
\text { - Olim Pompilidice. Pompilus is preoccupied. }
$$

The third transverse cubital cellule is triangular, the nerrures uniting in front; the upper half of the third transverse cubital nervure is obliquely bent; the first recurrent nervure is received not far from the apex, the second in the middle of the cellule; the transverse median nervure received very shortly beyond the transverse basal, almost interstitial; accessory nervure in hind wings received beyond the cubitus. Covered with a fulvous, pale pile; the antennal scape, sides and front of head, and, to a less extent, the top of the thorax with long fuscous hair. Mandibles, except at apex and the apical half of labrum, rufous. Palpi testaceous, darker at the base. Apex of clypeus transverse, the sides roundly oblique. Eyes slightly incised above the middle. Hind ocelli separated from the eyes by a slightly less distance than they are from each other. Occiput transverse. Temples almost obsolete above. Prothorax large, obliquely dilated from the middle to the tegulæ. Apex of metanotum with an oblique, straight slope, and thickly covered with longish blackish hair. Abdomen with broad, pruinose bands, the apical segment white above. Tarsal and tibial spines long and black; the long spur of hind tibiæ two-thirds of the length of the metatarsus. The antennal joints roundly dilated below. Tegulæ fulrous. The first and second joints of flagellum equal in length.

This is an Anoplius as now limited.

\section{Axorlius? pUlchrihirtus, sp. nov.}

Dark ferruginous, the greater part of the pleuræ, metanotum, a line above each antennæ, a mark on the ocelli, obliquely narrowed behind and incised in front, black; a line on the hinder edge of the pronotum and on the base of the second and third abdominal segments, pale lemon-yellow. Wings hyaline, slightly tinged with fulvous, the apex smoky; the stigma testaceous. $q$.

Length $9 \mathrm{~mm}$.

Cape Colony. Stellenbosch.

Eves distinctly converging above; the hinder ocelli separated from each other by a distinctly greater distance than they are from the eves. Apex of clypeus broadly rounded. Third joint of antenne not quite so long as the following two united. Apex of pronotum broadly rounded, with a narrow furrow in the middle. Metanotum covered with purple-coppery coloured depressed pubescence, as are probably also, in fresh examples, all the pleuræ. The spines on the legs are long and coloured like them; those on the fore tarsi are much longer; the under side of the posterior spinose; the claws bifid. Third abscissa of radius half the length of the second; transverse basal nerrure interstitial ; the recurrent nervures are receired 

near the apical third of the cellule; the accessory nervure in hind
wings received beyond the cubitus. The eves converge distinctly above and below, reach to the base of the eyes converge distinctly ment with a broadly rounded slope and mandibles; median segThe long spur of the tarsus. Labrum furrowed in reaches beyond the middle of meta curved apical tooth.

This species does

genera of Anoplini. Ishmead's (Pompilus) in the old sense.

\section{DIPLOPTERA.}

\section{Gen. ICARIA, Sauss.
Icaria capensis, Sauss.}

What I take to be this species is in the Grahamstown Museum The female is similarly. The worker only has been described. has the lower part of coloured, and 12-13 mm. long. The male dibles yellow; the antennæ front, the face, clypeus, and manyellow below; the above, testaceous and a serrated edge; the projectionsth joints project below, forming sharper, more oblique projections on the eighth to eleventh are is curved, stout, distinctly narrowed at on the others; the last joint species as regards colouration; narrowed at the apex. It is a variable on the mesonotum : the pleura there may be three large black marks and there may be a rellow line may be for the greater part black, radial cellule may be clouded.

\section{Gex. SMITHIA, Sauss.}

SMithia ? RUfipes, sp. nor.

Black; the under side of the antennal scape, clypeus, a line on the apex of the pronotum, the tegula and the apes of the line on the abdominal segments yellow; legs rufous, flagellum of antenna fuscous, darker above; wings hraline, tinged with fuscous viole ceous. 0 .

Length $7 \mathrm{~mm}$.

Cape Colony. Brak Kloof.

Head closely and coarsely punctured; the clypeus sparsely punctured; its apex black, depressed; it is roundly convex, sparsely pilose. Pro- and meso-thorax closely, strongly punctured. Median segment (including the pleuræ) alutaceous and thickly corered with silvery pubescence. Tegula large, conchiform, longer than broad. Abdominal petiole as long as the thorax. First transverse cubital nervure oblique, roundly curved downwards, the second not oblique roundly curved outwardly; the third straight; the first and second transverse cubital nerrures almost touching in front; second recurrent nerrure received near the apex of the cellule.

In $S$. natalensis the second cubital cellule is clearly appendiculated.

\section{Gex. RHAPHIGLOSSA, Saunders,}

Rhaphiglossa Flavo-ornata, sp. nor

Black; a curved line on the top of the clypeus, a spot on the inner side of the eye incision, a line on the under side of the antennal scape, a line on the apex of the pronotum, a small mark, longer than broad, on the scutellum on the sides, two large lines on the postscutellum. two oblique marks on the apex of the metanotum, two triangular marks on the apex of the first abdominal segment, a narrow line on the apex of the second, lines in the centre of the following three at the apex and a somewhat triangular mark (the broad end at the base) on the last, pale yellow; two small reddishyellow marks on the vertex above the antennæ; a broad rufous mark on the vertex behind, broad above, below reaching to the end of the eyes, becoming narrowed gradually below; the sides of the propleuræ narrowly above, the apex and middle broadly and a line behind the middle of the abdominal petiole red. Legs of a brighter red colour, the fore corm black; the tibix pale rellow on the outer side, the hind tarsi infuscated. Wings fuscous-violaceous, the stigma and nervures black. Basal half of antennæ red. Basal half of mandibles red on the inner side. $q$.

Length $15 \mathrm{~mm}$.

Cape Colony. Dunbrody.

Head closely and strongly punctured, more closely on the front than elsewhere; covered with a white down. Apes of clypeus almost transverse in the middle, the sides projecting into large leaf like expansions, roundly curved on the outer side, narrowed towards the apex, the outer border raised, the inner side straight. Thorax closely, rugosely punctured; the centre of the metanotum almost smooth, keeled down the middle. Metapleuræ sparsely punctured behind the middle and at the apex. Abdominal petiole faintly punctured, the other segments smooth and corered with a white pile. Petiole longer than the other segments united.

This species cannot well be confounded with $R$. natalensis, $\mathrm{Sm}$. 


\section{GEN. ODYNERUS}

Odyeres (LEIONOTUS) Whiteanes, sp. not.

Black; the clypeus, mandibles, except at the apex, the outer orbits almost entirely, the sides of the vertex broadly behind, antennæ, except the apical eight joints above, pronotum, scutellum, post-scutellum, the sides of the median segment broadly, an irregular spot on the base of the mesopleuræ above, the sides and apex of the basal two segments of the abdomen (the black basal mark large, broad at the base and narrowed in the centre), and the other segments almost entirely, red; the centre and the lower part of the eve incision, a mark above the antennæ, broader than long and slightly incised in the middle above, the sides of the clypeus above, a band on the apex of the pronotum, narrowed laterally, a small curred mark on the imner, hinder edge of the tegulæ, the raised hinder inner edge of the scutellum, the apex of the first abdominal segment above and of the second all round, yellow. Legs red, the knees and the four hinder tibix on the outer side pale yellow. Wings fuscoushyaline, the radial cellule and the apex all round darker violaceous; stigma dark testaceous, the nervures black. $q$ and $\delta$.

Length 11-12 $\mathrm{mm}$.

Cape Colony. Grahamstown, February; Brak Kloof.

Head closely and strongly punctured. Antennæ placed below the middle of the face. Clypeus slightly longer than its greatest width, its centre irregularly, longitudinally striated, the oblique sides punctured, the apex slightly, roundly incised, depressed in the centre. The apex of the mandibles and their inner side to near the middle black. Pronotum transverse, the sides not projecting much. The apical half of the sides of the scutellum are raised and stoutly keeled, its centre with a smooth furrow, which becomes wider towards the apex; the sides of the post-scutellum are more stoutly keeled. Sides of median segment broadly rounded. Second abdominal segment barrel-shape, longer than broad.

The male has the apical half of the clypeus whitish yellow; it is punctured, not striated; all the tibiæ are more broadly yellow, the antennal hook is stout and is fully longer than the last joint; the last abdominal segments are largely marked with black; the punctures on the clypeus do not run into striæ.

The amount of red and yellow on the body varies, as does also the size of the black marks on the basal two abdominal segments, Belongs to the group of $O$. tropicus, Sauss.

\section{ODYNERUS STELLENBOSCHENSIS, sp. nor.}

Black; the clypeus, labrum, mandibles, except at the apex, keel, a narrow line along the lower part of the eye post-scutellum and a narrow line on the apices of the incinal segments, pale yellow; a large rufous line the outer eye orbits, pronotum, an irregular on the upper half of the tubercles, mark, rounded a line down the centre. tegulæ, the median segre of the metabroad at the base, gradually narrowe pleuræ, the first abdominal segment, except for a large hour-gl except for shaped black mark in the centre, the second sed at the base and greatly a large black mark in the centre dilated at the base and and the dilated at the apex, the other segments, the antennalsous, under side of the flagellum, ferruginous. Legs fer fuscous violaceous, fore cosx and the posterior below yellow. Wings fous. $\delta$.

the nervures black,

Length $13 \mathrm{~mm}$.

Cape Colony. Stellenbosch

Cape Colony. Stellentosch. outer orbits Front and vertex sthe lower half, strongly keeled on the outer Clypeus abore, the apex roundly, deeply incised in the projections forming stout teeth. Thorax strongly projections forme base closely punctured, except on the apex of transverse, its sides rounded. of the meta-pleuræ; the pronotum trans on Scutellum furrowed down the middle, andly sloped on the apex. Metanotum with a steep slope, deeply furrowed in the centre, the sides broadly rounded. There is an oblique furrow on the basa me sides of the metasternum is a broad. half of the mesopleuræ; on plate. First abdominal segment cuprounded, pale yellow thin plate. First abdo

shaped, longer than its width at the apex.

\section{ANTHOPHILA.}

\section{GEx. PROSOPIS, Fab.}

Prosopis ribriplagiata, sp. not.

Black; a large mark on the clypeus, its lower half obliquely nar(he lower half of the inner orbits, 列 obliquely narrowed abore and below the antennæ, yellow; the sides 
of the clypeus broadly below, mandibles, the scape, under side of flagellum, a line on the pronotum, tegulæ, tubercles, the base and sides of first abdominal segment, the sides of the others more or less and the greater part of the rentral surface, rufous. Wings hyaline, the apex in front slightly smoky. Legs rufous. $q$.

Length $8 \mathrm{~mm}$.

Cape Colony. Dunbrody ; Grahamstown (Brak Kloof).

Metanotal area with some stout, irregular, curved strix. Front and vertex closely, regularly, and strongly punctured; antennal area large, raised, rugose and bounded laterally by curved keels. Clypeus strongly, but not so closely, punctured as the front; the cheeks almost smooth. Labrum rufous; the top broadly, roundly raised; the apex depressed, obliquely narrowed, aciculated and with a few scattered punctures. Mandibles black and rufous. Mesonotum sely, strongly and distinctly punctured; the scutellum as strongly, but not so closely punctured. Pleura and breast coarsely rugose and thickly covered with white pubescence; the metanotum more closely rugose. Post-scutellum opaque, very sparsely punctured. Abdomen smooth, the apices of the segments with a narrow band of white pubescence. Both the recurrent nervures are interstitial. The male wants the red lateral marks on the clypeus. Both sexes vary in the amount of the rufous colour which they bear; the yellow line on the pronotum may be tinged more or less with rufous. The malar space obsolete.

\section{Prosopis curvicarinata, sp. nor.}

Black; the clypeus, face, the yellow continued to the middle of the eyes, the mark becoming obliquely narrowed above, tegulæ, anterior tibiæ in front and the front tarsi, a broad line on the base of the hind tibiæ and their tarsi, lemon-yellow; flagellum of antennæ brownish, black abore; wings clear hyaline, the stigma and nerrures black. $\delta$.

Length $3 \mathrm{~mm}$.

Cape Colony. Pearston.

Head, pro- and meso-thorax closely, strongly, and clearly punctured; the metanotum rugose, the metapleurx more finely and closely punctured; the face and clypeus with the punctures large and distinctly separated; the metanotal area irregularly longitudinally striated. First recurrent nervure received in the apex of the first cubital cellule, the second interstitial. Between the antennæ are two stout keels which are roundly curved above, and have an indistinct one between them. Flagellum stout, the joints longer than broad except the penultimate.

The front is more strongly punctured than the vertex; there is a narrow keel down its middle. The eyes distinctly converge below: there is no malar space.

\section{Prosopis 5-Lineata, sp. nov.}

Black, shining, a narrow line on the outer and inner eye orbits and a slightly narrower one down the centre of the clypeus, pale yellow; wings smoky-hyaline, the nervures and stigma black. $q$. Length $7 \mathrm{~mm}$.

Cape Colony. Stellenbosch.

Face and clypeus distinctly, but not closely punctured, the punctuation on the apex of clypeus closer and stronger. Front strongly keeled; the centre with a bordered keel which bifurcates above. Malar space small. Labrum strongly punctured. Thorax shining; the mesonotum and scutellum smooth; the metanotal area strongly, closely aciculated; on the apex is a large, deep forea, wide below, gradually narrowed above. Pleuræ thickly corered with longish white pubescence; the tubercles behind bordered by a dense band of white pubescence. The hair on the ventral surface is dense and white. The apical dorsal segments covered with black hair. The pubescence on the tibiæ and tarsi long, dense, and grey. Both the recurrent nerrures are received in the second cubital cellule; the first at a greater distance from the base than is the second from the apex. The base of the thorax is rounded above. Third joint of antennæ fully twice the length of the fourth; the joints not very sharply separated.

\section{Gex. COLLETES, Latr.}

Colletes? capensis, sp. nov.

Black; the head, thorax, and, to a less extent, the abdomen, densely corered with longish clear white hair, the hair on the scutellums long and more fulvous in tint; the wings clear hyaline. the nervures and stigma black; the basal ventral segment dilated, broadly roundly incised in the centre; apex of mandibles piceous. $\delta$. Length 7-8 $\mathrm{mm}$.

Cape Colony: Pearston.

Front and vertex closely rugosely punctured, a beel below the ocelli. Clypeus smooth, more shining, as strongly, but not so closely, punctured as the front. Labrum smooth and shining, furrowed in the midale. Mandibles keeled down the middle and on the sides, the three keels not reaching to the apex. Pro- and 
meso-thorax closely and strongly punctured; metanotal area stoutly, irregularly striated round the edges, the centre less strongly than the base and apex. Abdomen closely and rather strongly punctured: the edges of the segments pale; the last broadly rounded.

Head as wide as the mesonotum, the temples obliquely narrowed; the malar space large, as long as the antennal scape, striated; eyes parallel, not converging above or below. The second cubital cellule in front is fully one-fourth longer than the third; the second recurrent nervure is roundly curved outwardly below; the cubitus ends shortly beyond the third transverse cubital nervure.

Unfortunately my dissection of the trophi of this species has not proved a success, and I am not quite certain if the tongue be broad or pointed, but on the whole it agrees better with Colletes than with Andrena to which it has a great resemblance. The first joint of the labial palpi is thicker than the others; it is as long as the fourth, the niddle two being shorter.

\section{Gex. HALICTUS, Latr.}

Halictus robertianus, sp. nov.

Black; densely covered with white pubescence, the apex of the clypeus (the yellow in the centre triangularly projecting into the black upper part), the lower part of the antennal scape, the apex of the femora (the anterior more broadly than the others), the tibix and tarsi, pale yellow, the tibiæ on the outer side marked broadly with fuscous; the wings clear hyaline, the nervures and stigma pale testaceous; metanotal area closely, irregularly, longitudinally striated, the striæ twisted and intermixed with some thimner transverse ones. $\delta$.

Length $5 \mathrm{~mm}$.

Cape Colony. Pearston.

Face and upper part of clypeus closely, minutely, distinctly punctured; the yellow apex of the clypeus smooth; front and vertex less distinctly punctured. Basal two-thirds of mandibles pale vellow, the apex piceous. Thorax closely, uniformly, minutely punctured; there is a smooth, narrow, impressed line on the basal half of the mesonotum in the centre. Tegula testaceous. Second and third cubital cellules in front almost equal in length.

Allied to $H$. albidus, Lep.

HALICTUS RUBRICALDIS, sp. nov.

Black, the apical half of the last abdominal segment and the rima rufous; the head, thorax, and rentral surface of abdomen densely covered with long cinereous pubescence; the base and apex of the second to fourth dorsal abdominal segments with a band of cinereous pile; the wings clear hyaline, the stigma and nerrures dark testaceous; the tarsi ferruginous below, cinereous abore; the knees and apex of tibia rufo-piceous; metanotal area rugosely punctured in the centre, the sides closely, finely reticulated. $q$.

Length nearly $8 \mathrm{~mm}$.

Cape Colony. Pearston.

Face projecting roundly in the centre, finely and closely punctured; the clypeus shining, sparsely punctured on the basal two-thirds. Front and vertex opaque, alutaceous. Mandibles broadly rufous in the middle; they are, as is also the labrum fringed with long, golden hair, the hair on the hinder edge of the vertex being also tinged with golden. The flagellum of antennx dark rufous, black above. Mesonotun closely, uniformly, and somewhat strongly punctured, the scutellum as strongly, but not so closely punctured. The apex of the metanotum has a steep slope; slightly, the sides broadly rounded on either side of the central depression, the edges being smooth and shining. Pleuræ closely, finely rugose. Abdomen at the base closely. and distinctly punctured, the third and following segments only indistinctly punctured; they are not depressed; the anal rima is large and conspicuous; the epipygium has a large tuft of rufous hair on the apex. Tegulæ piceous.

\section{HALiCtLS PEARSTONENSIS, sp. not.}

Black, shining: the apex of the first and the greater part of the second, third, and fourth abdominal segments rufous; the knees and tarsi fuscous; wings clear hyaline, the nerrures and stigma black. $\delta$.

Length $5 \mathrm{~mm}$.

Cape Colony. Pearston.

Front, face, sides of clypeus and cheeks densely corered with long, white pubescence; the face closely punctured, the clypeus much more strongly and sparsely punctured; the front and rertex more closely and less strongly punctured than the face. Pro- and mesonotum shining, covered, but not thickly, with white pubescence; the post-scutellum thickly covered with fuscous pubescence; the metanotal area finely, closely rugosely punctured, the punctures running into reticulations on the sides. Pleuræ opaque, alutaceous, obscurely striated. Abdomen smooth and shining; the base, apex, and rentral surface corered sparsely with long, white pubescence. 
The hair on the legs is white; on the lower side of the tarsi pale golden.

The apex of the metanotum has an oblique slope; the reddish second and third abdominal segments are almost bare; the sternum thickly covered with long, white hair; the ventral segments are transverse at the apex; the last is broadly, bluntly rounded at the apex, with the sides slightly obliquely narrowed.

\section{Halictes lamprovotus, sp. nov.}

Black, shining, impunctate except on the metanotal area which is finely and closely punctured; tegulæ piceous behind; under side of flagellum brownish; mandibles piceous towards the apex; wings clear hyaline, the stigma and nervures fuscous, the second and third transverse cubital and the recurrent nervures paler. Apices of the abdominal segments piceous, the anal rima rufous, the end of the segment pale fulvous. $q$

Length $4 \mathrm{~mm}$.

Cape Colony. Pearston.

Front and vertex closely, microscopically punctured; the face and clypeus very smooth and shining; the face not projecting much in the centre and not clearly separated from the clypeus. Eyes slightly converging above. Abdomen very smooth and shining; the ventral fringe white; the segments not depressed. Hind tarsi piceous. Third cubital cellule in front about one-quarter longer than the second ; the third transverse cubital nervure is almost straight below, the upper part roundly curved towards the stigma; the first recurrent nervure is received near the apex of the cellule, clearly separated from the transverse cubital; the second near the base of the apical third of the cellule.

\section{Halictus thestis, sp. nov.}

Black, shining, covered with white pubescence; the apex of clypeus pale lemon-yellow; the labrum, knees, and tarsi whitish testaceous; the scape of antennæ and upper side of flagellum black, the rest of flagellum brown; wings clear hraline, the stigma fuscous, the nerrures black. $\delta$.

\section{Length $4 \mathrm{~mm}$.}

Cape Colony. Stellenbosch.

Face and clypeus closely punctured, thickly covered with white pubescence; the face raised in the centre; the front and vertex opaque, granular; sparsely pilose; the outer orbits thickly covered with white hair. Mandibles yellow, their apex piceous. Thorax closely punctured, the scutellum less and the pleuræ more strongly than the mesonotum. Metanotum opaque, alutaceous, the base finely, irregularly, indistinctly striated. There is a short furrow on either side of the mesonotum near the base. Second cubital cellule distinctly narrowed in front; the tirst recurrent nervure received near the apex; the second shortly beyond the middle of the cellule. The second abdominal segment is distinctly, the third less distinctly depressed at the base. The eyes are long, converge below and clearly incised on the inner side.

\section{Halictus Dispositus, sp. nor.}

Black, shining, the hair bright white: flagellum testaceous below towards the apex; wings clear hyaline, highly iridescent, the stigma dark testaceous, the nervures black. $q$.

Length $5 \mathrm{~mm}$.

Cape Colony. Pearston.

Metanotal area closely, distinctly reticulated, the sides more irregularly obliquely striated. Clypeus strongly, deeply, irregularly, but not closely punctured. Face with shallow, scattered punctures; the front and vertex closely minutely punctured; on the upper half of the front is a shining, impressed line, on the lower a fine keel which extends to between the antennæ. Pleuræ opaque, coarsely granular; a deep, oblique furrow below the tubercles. Abdomen shining, impunctate, the apices of the segments pale testaceous; the anal rima blackish, the sides except at the apex distinctly margined, the apex depressed, rounded behind, dark testaceous. Labrum covered with stiff black hairs, which give it a striated look. The third transverse cubital nervure is broadly rounded; the first recurrent nervure is almost interstitial, being received in the extreme apex of the cellule.

\section{Halictes ethiopicus, sp. nov.}

Black; the abdominal segments broadly banded with rufotestaceous; legs bright rufo-testaceous, their tibiæ streaked with yellow; the coxæ, trochanters and base of anterior femora black; mandibles piceous, black at the base; antennæ black, the flagellum testaceous below; wings clear hyaline, highly iridescent, the stigma and nervures pale testaceous, the costa darker; the apical nerrures beyond the third transverse cubital nervures almost obsolete. $\rho$.

Length nearly $6 \mathrm{~mm}$.

Cape Colony. Pearston.

Netanotal area finely closely reticulated. Head and thoras 
smooth and shining; the face and clypeus with faint purple tints; the latter fringed with golden hair. Tegulæ piceous. Legs thickly covered with long, white hair. Ventral hair long and white. Anal rima rufo-testaceous like the rest of the segment, smooth, with an impressed line down the centre.

\section{Halictus interstitinervis, sp. nov.}

Black; the hair and pubescence dense and white except on the under side of the tarsi where it is bright red; anal rima fuscous in the centre; wings clear byaline, the stigma fuscous, the nervures black; the first recurrent nervure interstitial. $q$.

\section{Length 6-7 mm.}

Cape Colony. Stellenbosch.

Antennæ brownish beneath towards the apex. Clypeus shining, distinctly punctured, the punctures large and clearly separated; the centre of the face raised, minutely punctured; the front and vertex closely and finely punctured. Mandibles shining, black. Mesonotum and scutellum closely, distinctly, finely punctured; the basal half of the former with a distinct, clearly defined furrow in the centre; the post-scutellum thickly covered with griseous hair. Metanotal area irregularly striated to near the apex; the striæ in the middle forming almost reticulations. Pleuræ alutaceous. The second and third cubital cellules in front are almost equal in length ; the third transverse cubital nervure roundly curved; the first recurrent nervure interstitial ; the second received in the apical fourth of the cellule. Abdomen shining, closely, microscopically punctured; the base of the segments with a band of greyish powdery pubescence; above it is almost without hair; the ventral scopa clear white.

\section{Halictus LIPPANi, sp. nov.}

Black, the hind knees and tarsi white, the apical tarsal joints tinged with fulvous; the apex of clypeus broadly pale lemon-yellow; flagellum of antennæ dark brownish beneath; the head in front and pleure thickly covered with white pubescence; wings hyaline, the nerrures and stigma black. $\delta$.

Length $7 \mathrm{~mm}$

Cape Colony. Grahamstown. (Glen Lynden, January.)

Face closely, the clypeus more strongly and sparsely punctured; the front and rertex more closely and rugosely punctured except below the ocelli. Base of mandibles yellow. Pro- and meso-notum closely, strongly punctured; an impressed line on the basal half of the latter; the plemio closely rugose. Metanotal area in the centre coarsely reticulated, the sides obliquely striated; the rest of the segment except behind the area closely rugose. Abdomen closely strongly punctured, the punctuation becoming weaker towards the apex; the third and fourth segments obliquely depressed at the apex; the apices of the last two smooth. The first recurrent nerrure is interstitial.

This species is closely related to what I take to be $H$. albidus, Lep. ; the two may be separated thus (the males of both only are known):-

Length $7 \mathrm{~mm}$.; antennæ not reaching to tip of thorax, dark coloured below; metanotal area coarsely reticulated in the middle, the sides stoutly obliquely striated; the stigma and nerrures black, the first recurrent nervure interstitial; the

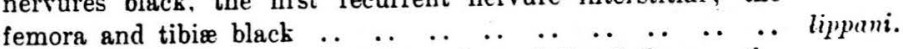

Length 5-6 mm.; antennæ reaching beyond tip of thorax; the Length 5- light ; antennalow; metanotol ares closely reticuflagellum light testaceous below, metanotal area closely reticulated ; the stigma and nerrures pale; the first recurrent nerrure

not interstitial; the femora and tibiæ in part rellowish white.. albidus, Lep.

When fresb both species have probably the abdominal segments banded with depressed white pubescence.

\section{Halictus CAPICOLA, sp. not.}

Black; the head and thorax thickly covered with long cinereous hair, the depressed bases of the abdominal segments with cinereous pile, the ventral surface covered with long cinereous hair; the anal rima dark piceous-rufous, the sides and apex of the segment being similarly coloured; metanotal area strongly irregularly longitudinally striated, its apex more closely finely and less distinctly striated. Wings hyaline, iridescent, the nervures and stigma black. $q$.

Length $8 \mathrm{~mm}$.

Cape Colony.

Clypeus strongly punctured to shortly beyond the middle, the punctures large and distinctly separated; the apex smooth except for a few elongated punctures. Mesonotum closely punctured and with an impressed line on either side of the middle: the centre of scutellum smooth, the sides sparsely, indistinctly punctured. Abdomen smooth, a transverse, minute furrow on the second and third segments. The apical joints of the tarsi are piceous; the hair on the under side bright rufous.

\section{GEx. ANDRENA, Latr.}

ANDrexa malma, sp. nor.

Black; the head with long white, the thorax with rufo-fulrous pubescence, the hair on the pleuræ and sternum paler than it is on 
the mesonotum; the abdominal segments with broad bands of depressed white pubescence; the hair on the legs long, white; the tarsi rufous; wings hyaline, the stigma fuscous, the nervures black. $q$.

Length $10 \mathrm{~mm}$.

Cape Colony. Brak Kloof ; Grahamstown.

Front and vertex closely punctured; a stout keel between the antennæ; the face and clypeus more strongly punctured, the punctures becoming larger and more confluent towards the apex of the clypeus; malar space finely, closely striated; labrum smooth and shining, deeply furrowed in the centre. Pro- and meso-thorax closely and strongly punctured, the punctures round; the metanotal area strongly irregularly striated, the striæ running into reticulations; the reticulated central part shorter than on the sides, the smooth part continued to the apex of the segment, becoming gradually narrowed, its apical half depressed, the conrex upper part keeled in the middle. Basal abdominal segment covered with long white, slightly tinged with fulvous, hair; the pilose bands extend on to the ventral surface; the segments are closely, minutely punctured; the apical two fuscous at the apex; the last segment thickly covered with stiff black depressed hair which gives it a striated appearance. Hair on legs white; the calcaria rufous.

Male similar; the antennæ stouter, not much longer than in the female; the clypeus smoother at the apex.

The abdominal bands appear to be lead-coloured under the white pubescence. Tegulæ piceous.

\section{ANDRENA MATHA, sp. nov.}

Black, a narrow white line on the base of the pronotum; legs black, the tarsi, anterior tibiæ in front and the whole of the posterior rufo-testaceous; wings uniformly dark fuscous violaceous, the nervures and stigma black. $\uparrow$.

Length $9-10 \mathrm{~mm}$.

Cape Colony. Brak Kloof. Also an old specimen marked "Transvaal."

Head and thorax closely, strongly, uniformly punctured; the metanotum as closely, but not so strongly punctured; its base strongly, but not closely longitudinally striated. The hair on the front of the head is longish, brownish-rufous. Labrum depressed in the middle at the apex, smooth and shining. Apex of clypeus densely fringed with long dark rufous hair. Base of mandibles rufous. The hair on the apex of the tarsi and on the tarsi bright rufous: on the scopa dark fuscous. Pygidium densely covered with stiff depressed fulvous pubescence, which gives it a striated appearance; the centre is furrowed.

The tegulæ are large, conchiform, piceous or pale on the outer edge; the occiput almost transverse; the metanotum is shorter and has a steeper slope than usual; the abdomen is also shorter than usual compared with the thorax. The insect is broader and stouter than usual.

\section{Gex. NOMIA, Latr. \\ Nomia Dalyana, sp. nov.}

Black; the head, thorax, and base of abdomen covered with long cinereous pubescence; the abdominal segments banded with depressed pubescence of the same colonr slightly tinged with fulrous: the last segment ferruginous, its sides covered with pale golden pubescence; legs fulvo-rufous, all the coxæ, trochanters, the fore femora above and below, the middle entirely, the hinder broadly above and a large mark on the basal half of the middle tibiæ on the outer side, black; wings hyaline, tinged with fulrous, the apex of both fuscous violaceous; the stigma fulvous, the nerrures blackish. $\sigma$ and $q$.

Length $10 \mathrm{~mm}$.

Cape Colony. Grahamstown.

The male hind femora are greatly swollen, broadly rounded abore. straight below, with a short, stout, oblique tooth in the middle; the hind tibiæ narrow at the base, becoming gradually wider towards the apex, which, on the lower side, is produced into a bluntly rounded process, more than twice the width of the base of the metatarsus. which is simple, of uniform width, and not longer than the other joints united. Antennæ black, the scape corered with long fulrous hair. Head closely punctured, more strongly, rugosely on the front. Mandibles fulvo-testaceous, black at the apex. Thorax more strongly. and not quite so closely punctured as the head; the scutellum slightly. depressed in the middle. Metanotal area clearly defined by a kee behind, strongly but not closely striated ; the segment behind it closely rugosely punctured. Abdomen closely and strongly punctured, the second segment and, to a less extent, the third depressed at the base: the bands under the pubescence are lead-coloured. Tegulæ piceous. The female similarly coloured; the hind femora and tibiæ not dilated; the pubescence on the legs denser and longer; the femora not toothed.

Comes near to X.calida, West.; the two may be known, inter alit. by the different shapes of the hinder legs; in Dulyana the hind 
:44 Transactions of the South African Philnsophical Socict?.

emora are straight at the base below; in caliula roundly, broadly -urved to the tooth; in calicla the tibiæ are more produced at the :urved to the the process longer, sharper, it being very much longer ompared with the width of the metatarsus; the black colour on compared with the balida; in dalgan $t$ does not extend below anywhere.

\section{Ges. CERATINA, Latr.}

Ceratina macelivextris, sp. nor.

Dark green, largely marked with blue and coppery-brassy tints; Dark greed lines in the the clypeus, exces, mandibles, except at the apex, where they centre, labrum, cheeks, mandibles, except at the apex, whe line on the are piceous, the greater pentellum, a curved line behind it, pronotum, tegulæ, tubercles, scutellum, a curved line behind it, extending to the wings, post-scutellum, and the abdom for some irregular curved blackish lines and marks, the apex of femora, tibiæ, and tarsi, pale bright yellow; wings clear hyalin the nerrures and stigma pallid testaceous. $q$ and $\delta$.

Length $3 \mathrm{~mm}$.

Cape Colony. Pearston.

Antennal flagellum brownish testaceous, blackish above. Head an thorax closely, minutely punctured and thickly covered with longish white pubescence; the clypeus with some large, separated longish white pubescence, the cly from the ocelli. punctures in the middle, a narrow furrow runs down mesonotum, and There are three narrow furrows on the base of the mesonotum, and in the middle, outside these, a shorter, wider one. The metanotum is more strongly and distinctly punctured than the rest of the thorax. Abdomen smooth and shining; the black marks on the back rary on the basal two segments there may be two broad curved lines; on he others black lateral lines; or there may be hardly any black the apical segments covered with longish soft white hair; the scopa white. Legs thickly covered with long white hair; the hinder tibix whe lined with black on the outer side.

The marks on the clypeus may be absent; there may be a transverse vellow mark on the face above it ; the scutellum may be marked with black on the apex and the ventral segments may mer. probably the number and be marked with black at the sides. Very probably the numb size of the black markings on the body and legs vary. The apical two ventral segments may be largely black. The second and third cubital cellules are narrowed in front; the second is about one-half the length of the third in front; the first and second transverse cubital nerrures are roundly curved.
Some Nere Genera and Species of Hymenoptera.

The genus Ceratina is probably well represented in South Africa. Mr. Stadelmann (Die Hymenopteren von Ost-Afrikas, p. 3) state that he knows eight species which agree with the description of C. capcnsis, $\mathrm{Sm}$. Col. Bingham informs me that my species is not in the British Museum Collection.

\section{GEN. ALLODAPE, Lep.}

Allodape foveiscetis, sp. nov.

lack, smooth, and shining; the clypeus, the curved, raised innel orbits, labrum, an oblique spot on the outer edge of the malar space, and scape, a broad band, roundly 作 dilated, on the upper side of pron femora broadly, tibiæ and tarsi vellow; the abdomen, apex of femora bright rufous; the fore femora, on the apical the stigma and nervures lemon-yellow; wings clear hyaline, the stigma and ner fuscous. $d$.

Length nearly $5 \mathrm{~mm}$.

Cape Colony. Pearston.

Thoth and shining; the clypeus sparsely, distinctly punctured Tips of mandibles rufous. Front the metanotal area aciculated. ITs of mandibles rufous. Fronum densely covered with long, white pubescence; sout bare. The first with long pale hair, the rest of the thorax almost bar the apex with abdominal segment is marked at the base and near the apetured and fuscous; the apical segments are darker colous dense, white; on the covered with white hair. Hair on the legs dense, white; on the comora it is long. The second recurrent nerrure is received at a greater distance from the apex than is the first from the base of the cellule.

The scutellum is furrowed in the middle ; this furrow has oblique The scutellam is furowsion with the sides, the whole forming a narrow, clearly narrow end at the base; the

defined furrow in the centre.

Allodape melanopus, sp. nor.

a very irregular $T$-shaped mark on the Black, the abdomen red; a very appearing clypeus, its sides irregularly indented and as if it formed a separate line, a large, irre narrowed laterally on the scutellum, a large 
below, lemon-yellow. Antennal scape rufous below. Legs black, the knees and fore tibia rufous. Wings hyaline, the stigma and nervures black. $q$.

Length $5 \mathrm{~mm}$.

Cape Colony. Pearston.

Labrum and tips of mandibles brownish; the former with scattered punctures. Head and thorax smooth and shining; the base of metanotum strongly aciculated; the pleuræ sparsely pilose. Apical segments of abdomen punctured and corered with white pubescence. The hair on the legs whitish, long and dense on the hind tibiæ, on the hind tarsi it is darker coloured. The second cubital cellule in front narrowed, being there not much more than half of its length behind; the second transverse cubital nervure is straight and oblique; the first recurrent nervure is received close to the first transrerse cubital, almost touching it; the second is received further from the apex.

Allod

Black, smooth and shining, the apex of clypeus shagreened; a large yellow mark down its centre; it is broadly dilated above, the upper edge roundly incised, the narrowed lower part becoming narrowed below, its sides irregular; the apex and the labrum fuscous, the latter with a few large punctures. Wings hyaline, the stigma and nervures black, the first recurrent nervure received at twice the distance from the base, that the second is from the apex. $q$.

Length nearly $5 \mathrm{~mm}$.

Cape Colony. Pearston.

Ocellar region minutely punctured; the frontal furrow acute; flagellum brownish below; there is a row of punctures along the lower inner orbits, inside the keel; metanotal area minutely punctured; tegulæ fuscous, yellow on the outer side; below and slightly in front of tegulæ is a large pale rellow mark, longer than broad, with straight sides. The hair on the legs thick, long, white, darker coloured on the tarsi which are tinged with testaceous; the spurs pale testaceous. As usual the apical abdominal segments are punctured and pilose. Wings highly iridescent. The lower edges of the top part of the clypeal mark are rounded and do not project downwards.

Allodape prisglei, sp. nor.

Black; a large mushroom-shaped mark on the clypeus, dilated below, but not so widely as above, a broad line on the pronotum, tubercles, a large mark on the scutellum, roundly narrowed laterally. and the tubercles, bright lemon-yellow; the knees, tibiæ and tarsi rufous, the fore femora with the apical third lemon-yellow below. Scape of antennæ rufous, the flagellum fuscous below. Wings hyaline, the stigma and nerrures dark fuscous. $?$

Length $\tilde{j}-6 \mathrm{~mm}$.

Cape Colony. Kokstad; Brak Kloof.

Smooth and shining, including the clypeus; labrum strongly. punctured; the base of metanotum aciculated, broadly depressed in the middle. Mandibles black. Base and apex of abdomen blackish; the latter with scattered white hairs. Hind tibiæ infuscated in the middle. Both the, recurrent nerrures are received close to the cubitals.

\section{Allodape fuscinervis, sp. nor.}

Black, shining, the abdominal segments narrowly banded with fuscous at the apex, antennal flagellum brownish belor; the mark on the clypeus dilated above and below, the central stem with irregular edges; the cross top part transverse above, the sides straight, the lower side slightly dilated at the outer edge, the whole thinner than the central stem; the dilated apex larger, transrerse below, laterally extending to the longitudinal facial furrors, the upper part with the yellow suffused into fulvous; wings clear hyaline, the stigma and nerrures fuscous; the recurrent nerrures received about the same distance from the cubitals; tegular piceous. $q$.

Length $5 \mathrm{~mm}$.

Cape Colony. Brak Kloof.

Clypeus closely, minutely and distinctly punctured, most strongly at the apex. Labrum yellowish, with two large punctures on either side. Apex of mandibles broadly piceous. Frontal furrow narrow. distinct. Metanotal area opaque, strongly aciculated. Tubercles pale yellow, fringed above with pale hair. Hair on legs long and silvery white; the apices of tarsi testaceous.

\section{Gex. CROCISA, Jurine.}

\section{Crocisa fulvo-hirta, sp. not.}

Black; the head, pronotum, pleuræ, base of metanotum and bands, broader than long and extended backwards along the sides, near the apices of the basal four abdominal segments, the bands not reaching to the middle, of pale fulvous, longish pubescence, the temples, centre of mesonotum and metanotum, the lower side of the pleurix 
and the sternum thickly coveled with black pubescence; the hair on the legs black; the outer side of the four hinder tibia thickly covered with depressed white pubescence, on the apices of the hinder tarsal joints the pubescence is white, on the lower part of the metatarsus soot-coloured; wings fuscous-violaceous, spotted with hyaline in the middle. $q$.

Length $12 \mathrm{~mm}$.

Cape Colony.

Face and clypeus closely, uniformly punctured, the transverse apex of the latter smooth, the front and vertex more strongly punctured, more sparsely round the ocelli. Mesonotum and scutellum closely and distinctly punctured, the former depressed in the centre, the depression wide, deepest in the centre. Scutellum not flat as usual, and distinctly punctured, narrowed slightly towards the apex, which, in the centre, is roundly depressed; the sides tuberculate abore; it does not project over the metanotum. The apices of the first and of the fifth and sixth abdominal segments project obliquely at the apex. Mandibles rufous at the base.

This species has not the flat, plate-like, projecting scutellum of the typical species of the genus, but otherwise appears to be a typical Crocisa.

\section{Gex. MEGACHILE, Latr.}

Megachile robertiana, sp. nov.

Black ; the hair on the head, thorax, apex of abdominal segments, ind the basal half of the scopa, clear white; the apical haif of the scopa bright red; wings clear hyaline, the nervures and stigma slack. $q$.

Length $7-8 \mathrm{~mm}$; breadth $3 \mathrm{~mm}$.

Cape Colony. Pearston; Grahamstown.

Mandibles, except at apex, thickly covered with white hair; ehind the apes is a tuft of reddish pubescence: subapical tooth horter and more broadly rounded than the apical; behind it is a road, shallow incision. Clypeus strongly and closely punctured, oundly convex; its apex in the centre is slightly roundly incised nd depressed, this central part being narrower than the sides. 'he face is not so strongly nor so closely punctured as the clypeus ; se front and rertex are more strongly and quite as closely punctured s the clypeus; the latter is not quite so closely punctured down the nntre. Head as wide as the thorax, which is closely and uniformly unctured, except on the metanotum, where the punctuation is eaker and sparser. Legs black; the hair white except on the nder side of the tarsi, where it is bright red; the metatarsus not quite so wide as the apex of the tibiar, three to four times longer than broad. Tegulæ black.

This species looks very like the Indian M. hera.

\section{Megachile prionsa, sp. nov.}

Black ; closely and strongly punctured, the abdomen less strongly Ben the thorax; the lower part of front, face and clypeus thickly covered with longish clear white pubescence; the pleuræ and sternum covered with long white, the mesonotum with shorter, sterned clear white pubescence, white, slightly tinged with fulvous; wings hyaline, the apical balf tinged with violaceous; the nerrures and stigma black. $q$.

Length $7 \mathrm{~mm}$.

Cape Colony. Brak Kloof.

Base of mandibles shining, distinctly punctured; the rest opaque, finely rugose and irregularly striated, the outer edge keeled; and there is another keel inside this, not reaching to the base; the apex bidentate, the subapical tooth broader, shorter, and more rounded than the apical. Inner orbits keeled, the space between the keel and the eyes irregularly striated. Apex of clypeus transverse, with an irregular edge. Apical slope of metanotum smooth, almost shining, clearly margined above, the sides broadly rounded, slightly depressed in the middle; the basal area stoutly striated, narrom in the middle, widened laterally. The apical slope of abdomen smooth, stoutly keeled all round above; the apical secment with a thick band of pale fulrous pubescence. Some specimens bave the wings more violaceous than others; the second recurrent nerrure is almost interstitial; tegulæ black. There is a transverse furrow or depression near the base of the second abdominal segment.

\section{Megachile comhala, sp. nor.}

Black; the abdomen covered with ferruginous pubescence; the apex of thorax and base of abdomen in both sexes with longer whitish hair ; the hair on the head and thorax in female black; the scopa pale fulvous; wings fuscous-violaceous, the nerrures and stigma black; the hair on the legs in female blackish, on inner side of tarsi rufous; on the male long, thick and white, rufous on the inner side of tarsi. Mandibles bidentate. $q$.

Length $14 \mathrm{~mm}$.

Cape Colony. Brak Kloof.

Mandibles at the base closely rugose, the middle with longish 
punctures and with stout striæ; the apical tooth bluntly rounded; the subapical much shorter, bluntly rounded. Clypeus closely rugose; the apex in the centre slightly broadly incised, the sides broadly rounded. Front with a distinct furrow down the middle. Thorax closely, strongly punctured; the hair on the top short, close and black: on the pleuræ and breast longer, denser and soot-coloured. The female of imitatu, as named by Smith for me, has the wings much lighter coloured, the mandibles behind the apical two teeth broadly bisinuate, which is not the case with comhala; the hair on the face and clypeus white and thick, not black and rather sparse; the hair on the thorax is lighter coloured, and the ventral scopa is paler at the base. I am somewhat doubtful about Mr. Smith's identification of his species; the specimens, however, are rubbed, and that may account for them not agreeing with the description.

The male has the face, clypeus, cheeks and oral region densely covered with long white hair; the front with long soot-coloured, the vertex with shorter black hair; the fore femora, tibix and tarsi are rufo-testaceous in front; the fore coxir armed with a stout longish tooth, which is broader and testaceous at the base; the basal joint of fore tarsi greatly dilated, pale yellow, densely fringed with long clear white hair below; the middle tarsi fringed with longer white hair, the hinder with rufous pubescence on the metatarsus, as in the female. The apex of the last segment is stoutly irregularly serrate: there are four or five teeth on either side, the number and form appear to vary in old examples; the central two are more widely separated than the others. The apical tooth in the male mandibles is longer and sharper pointed than it is in the female; it is probably abraded in the latter. Tegulæ black.

Appears to come close to M. imitutu, Sm., described in both sexes (Cat. Hym. Ins. Brit. Mus., i., 15s), but nothing is said about the apex of the abdomen in the male being denticulate.

\section{Megachile harthula, sp. not.}

Black; the head and thorax densely corered with long whitish hair, that on the mesonotum haring a fulvous tinge; the basal foul abdominal segments thickly corered with long fulrous pubescence, the fifth with long, stiff black hair, its apex with a band of pale depressed pubescence; the sixth sparsely with long black hair; the rentral surface rufo-fulvous, the segments fringed with pale pubescence; wings hyaline, the apex infuscated, the nerrures black; the sixth segment incised in the middle at the apex, the incision becoming gradually wider towards the apex, its base rounded; its bordering tooth has a short blunt tooth attached to its base on the outer side, outside are four irregular, but stout teeth. 3

Length $13 \mathrm{~mm}$.

Transvaal.

Mandibles bidentate, the teeth large; the subapical bluntls Des clypeus incised; the third antennal joint twice the length of the second, and distinctly shorter than the fourth. Head and thorax closely, distinctly punctured; the serenth abdoHead and thorax closel, distines, basal half, gradually, roundly minal segment becomes, o the apical half is distinctly narrowed narrowed to the middle, the apion compared with the basal; it is rounded and centre raised to a point the sides at the base are depressed; the centre rased to a point behind the middle, the apical portion of this central keel being thus the larger; both have oblique slopes. Fore coxix with stout, curved spines: the four apical joints of the tarsi are rufous: the hair on the under side of the tarsi fulrous.

\section{Megachile marl's., sp. nov.}

Black; the hair on the face, front, and thorax white; the Black rufous, white at the base; wings hyaline, the nervures black; tegulix fuscous. $q$.

Length $8 \mathrm{~mm}$; breadth nearly $3 \mathrm{~mm}$.

Transvaal.

Mandibles with two bluntly rounded teeth, the second smalle Mandibles wirst behind the second tooth they are broadly slightly the groove widest at the apex; outside it, on the apical half, is a narrower widest at the apex, ous closely in the centre of the clypeus, which has its apex depressed and clearly separated; it is transverse. Thorax closely, strongly punctured ; the metanotal it is transverse. Thoras closedy anctured above, without area coarsely aciculate Apical joints and the under side of the transverse hair on the legs cinereous : basal of the fore tarsi are testaceous; the hair on the liro-thirds of the the spurs pale testaceous; base of metatas shorter than the other width of the tibire; the metatarsus slighty furrow, bear elongate, joints united. The mandibles, inside the fursw, bale hair.

large punctures; they are sparsely coveriana, which may be known

This species comes close to $M$. robcrtine, from it by the basal half of the mandibles being densely covered with grey pubescence, the apical furrows are much less clearly defined; the apical two teeth more equal in size; the apex of the 


\section{Transactions of the South African Philosophical Society.}

clypeus not transverse in the middle and its sides roundly waved the hair is denser and longer both on the body and legs ; and on the under side of the tarsi it is bright red.

Megachile temora, sp. nor.

Black; the hair on the head and thorax white, on the apices of the abdominal segments of a clearer white; the abdominal scopa bright red; the hair on the tarsi and apex of tibiæ red, on the rest of the legs white. Wings hyaline, slightly violaceous at the apex, the stigma and nervures black. $q$.

Length $11 \mathrm{~mm}$.

Cape Colony.

Mandibles with three apical teeth; the apical sharper and longer than the others; behind the third is a short, less distinct one; the punctuation is strong and close; the hair sparse and pale red. Face and clypeus closely and strongly punctured; the apex of the latter transrerse, but with an irregular edge; the face more closely, and the front and vertex still more closely punctured. Thorax closely punctured, the punctures forming almost reticulations in places; a smooth, narrow furrow down the centre of the mesonotum; the hair on the pleuræ and metanotum long and dense. Metanotal area coarsely alutaceous; the rest finely closely reticulated. Apex of hind tibiæ smooth, depressed, with a raised broad keel in the centre; metatarsus slightly narrower than the apex of tibix, four times longer than it is broad; its outer side at the base with a rounded depression or incision; calcaria longish, curved, testaceous. The bair on the under side of the tarsi is long, thick, and bright red.

This species is not unlike M. imitata, Sm., as named for me by the late Mr. Frederick Smith; that has the mandibular teeth broader, especially the apical one at the apex; the punctuation is coarser, and the face is smooth in the centre; the pubescence on the mesonotum has a fulvous tinge, and it wants the central impressed line; the basal half of the scopa is white, the pile on the under side of the tarsi is not bright red, and the apex of the clypeus is straight, not with an irregular edge. In M. imitata the apical mandibular tooth is large. broad, bluntly rounded at the apex; the second is small, more oblique, and bluntly rounded; it is followed by two broad, rounded projections.

\section{Megachile sarsa, sp. nov.}

Black; the head, thorax, apex of abdominal segments, and the base of last abdominal segment broadly densely corered with snow-
Some Nen Genera and Species of Hymenoptera.

white hair: wings clear hyaline, the nervures and stigma black; apex of last abdominal segment roundly, deeply incised, the incision bounded by two longish, stout teeth, and with two much smaller teeth on either side, the outer tooth being smaller than the inner one. $\delta$.

Length 6-7 $\mathrm{mm}$.

Cape Colony. Stellenbosch

Mandibles closely punctured, the apex smooth and shining; the apical tooth long, becoming gradually narrowed to the apex, the subapical shorter, broader, and blunter; the base on the under side projects into a blunt, stout tooth. Head closely, rugosely punctured : the clypeus projecting, smooth and shining, the apex with a slight, but distinct incision, forming a broad curve. Pro- and meso-thorax closely and strongly punctured; the metanotum sparsely punctured, the area alutaceous, furrowed down the centre. Abdomen closely punctured, the punctuation becoming distinctly stronger towards the apex, the last segment being coarsely rugose. Fore coxæ with a stout tooth at the base, broad at the base, narrowed at the apex: the base of the tarsal joints testaceous.

\section{Gex. PODALARIUS, Latr. (ANTHOPHORA, Auct.).}

Podalarius ruficaudis, sp. nor.

Black; the hair on the vertex, upper part of thorax and of abdomen griseous, tinged with fulvous and tipped with black; on the face and sides of thorax white; the apices of the abdominal segments with paler bands, the penultimate segment and the sides of the last covered with long rufous hair ; the hair on the legs white, rufous behind; wings hyaline, slightly tinged with violaceous, the nerrures and stigma black. $\subsetneq$.

Length $12-13 \mathrm{~mm}$.

Transraal.

Clypeus and labrum closely, rugosely punctured; the former with a keel down the central half. Mandibles entirely black, the base with elongated, irregular punctures; the vertex and front shagreened, the ocellar region smooth and shining; a furrow leads down from the ocelli. The hair on the thorax is long and dense; there is a smooth, bare, shining furrow in the centre of the metanotum. Pygidium bare. Ventral scopa tinged with rufous at the apex. On the end of the penultimate joint of the hind tarsi is a tuft of bright red hair.

The male is similarly baired, except that the bands of paler hair on the apices of the abdominal segments are paler and more 
distinctly defined; the clypeus, labrum, a narrow line on the lower part of the face above the clypeus united to a large mark on the inner orbits which is triangularly incised above, a narrow line on the under side of the antennal scape and the basal half of the mandibles, yellow. The ventral segments are testaceous, narrowly yellow on the apex; the apices of the apical three slightly incised.

Allied to $P$. coccina, $\mathrm{Kl}$,, and fallax, Sm. Col. Bingham informs me that the species is not in the British Museum Collection.

Podalariles pallidicinctus, sp. nov.

Black; the lower part of the face, the part on the sides roundly incised above, clypeus, except for a curved black line along the upper half, the line narrowed above and below; labrum yellow, a black mark on either side of the top, the mandibles, except at the apex, yellow: the apices of the abdominal segments broadly banded witl pale yellow. Wings hyaline, the apex slightly infuscated. Head and thorax thickly covered with long white hair; the hair on the top of thorax broadly tipped with black. The hair on the under side of the four posterior tarsi rufous. Scape of antennæ broadly yellow below. Tegulæ pale testaceous. $\delta$.

Length $10 \mathrm{~mm}$.

Cape Colony. Stellenbosch ; Grahamstown:

Clypeus sparsely, the labrum closely punctured; the apex of the latter distinctly roundly projecting. Front and vertex closely, but not strongly punctured; a smooth line between the ocelli. The yellow abdominal bands are thickly covered with long white pubescence; the hair on the base of the segments sparser and darker ; anal spines longish, stout. Ventral surface broudly brownish in the middle.

What I take to be the female is in the Collection of the Albany Yuseum. It has the apices of the abdominal segments pale yellow as in the male, but corered by fulvous instead of white pubescence; the second cubital cellule as in it is distinctly shorter than the third in front; the apex of the clypeus is pale yellow and there is a pale yellow mark on the base of the mandibles; the ventral scopa is white and the sides and apices of the segments are testaceous; the hair on the base of the tarsal basal joint is rufous as in the male. Its length is $12 \mathrm{~mm}$. It was taken in June by Dr. Penther.

Podalaric's spilostonles, sp. nov.

Bluck; the head and thorax densely covered with long cinereous hair, which takes a fulvous hue on the upper parts; the basal four abdominal segments on the apex broadly banded with depressed pale fulvous pubescence; clypeus black; the sides, apex, and a stripe in the centre, which becomes gradually wider towards the apex, fulvotestaceous, the labrum similarly coloured except for a black line at the base, this line being dilated at the sides; on the apex of the face, in the centre, is a transverse line, which is dilated upwards in the middle. Legs brownish, the tibiæ and tarsi black in front; the hair dense and cinereous, on the tarsi behind rufous. Wings short, hyaline, the nerrures and stigma black. \&

\section{Length $10 \mathrm{~mm}$.}

\section{Cape Colony.}

Front and vertex closely, irregularly punctured, the ocellar region and a broad stripe along the sides of it smooth. Clypeus strongly and closely punctured, except along the central stripe where the punctuation is sparse. Labrum closely and strongly punctured, its apex smooth, black and slightly incised in the centre. Metanotal area aciculated. The basal half of the abdominal segments thickly covered with short, black depressed hair; the penultimate segment with a large triangular spot of black pubescence in the centre; the pygidial area dark brown, minutely, closely punctured. Ventral surface closely punctured, with the apical third of the segments brownish, the extreme apices lead-coloured.

The pubescence on the abdomen is shorter and more depressed than it is in the other African species known to me. The two large black marks on the clypeus are rounded and narrowed at the apex. Tegulæ piceous. Calcaria dark testaceous. The second cubital cellule is much narrowed in front, not half its width behind, being the length of the space bounded by the recurrent and second transverse cubital nervures and not half the length of the third in front; the third is narrower in front than behind, through the third transverse cubital nerrure bending obliquely in front towards the base of the cellule.

Col. Bingham informs me that this species is not in the British Museum Collection.

\section{Gex. HABROPODA, Smith.}

\section{HaBRopoda CAPENSIs, sp. nor.}

Black; a transverse mark, transverse in front, rounded behind, on the apex of the clypeus; the hair on the head and thorax long, dense and cinereous, on the apices of the abdominal segments bright fulvous, as it is also on the under side of the legs; the last joint of the tarsi rufous; anal rima black bart' wings 
hyaline, the apex slightly darker, iridescent, the nervures and stigma black. $q$.

Length $17 \mathrm{~mm}$.

Cape Colony: (Brak Kloof); Transvaal.

Face and clypeus closely, strongly punctured; the apex of the clypeus transverse, smooth, slightly raised ; the labrum more coarsely punctured and with a large tuft of long pale hair in the centre. Ocellar region smooth and shining, the rest of the vertex and front shagreened. Pro- and meso-thorax closely, strongly punctured ; the metanotum coarsely shagreened. The hair on the basal segment of the abdomen is long and white; on the second to fourth depressed, short, brighter and paler on the apices of the segments; on the penultimate segment it is much longer and fulvous. The anal rima coarsely shagreened. The mandibles are black at the base, the apex broadly cream-coloured. The hair on the legs is very long and dense; on the outer side of the hinder tarsi is a shield-shape plate, broad at the base, becoming roundly narrowed towards the apex and covered with depressed fulvous pubescence.

I only know the female of this species. I am not sure but that Macrocera capensis, Lep., may be its male. My species is a true Habropoda.

\section{PLESIANTHIDIUM, gen. nov.}

Similar to Anthidium, but with the maxillary palpi 3-jointed and the mandibles unidentate.

This genus is founded on a large species, densely haired on the head, thorax, and abdomen, and having the general form and abdominal structure of Anthidinm, but sufficiently distinguished from it by the characters noted above. The first recurrent nervire is almost interstitial, the second received distinctly beyond the second transverse cubital. The abdomen wants entirely the yellow markings found on most species of Anthidium. The first and third joints of the maxillary palpi are about equal in length; the middle one is as long as both united and thicker than them; the labial palpi are as in Anthidium, the trophi being long as in that genus. The mandibles, behind the apical tooth, are straight.

\section{Plesianthidiun fulvopilostm, sp. nov.}

Black, the clypeus yellow; the upper part of the head and thorax thickly covered with long bright fulrous, their lower parts with long white hair; the upper part of the abdomen with fulvous, the ventral surface with paler pubescence; wings fuscous-hyaline, suffused with violaceous tints; the nervures and stigma black. $\delta$.

Length 15-16 mm.

Cape Colony. O'okiep.

Head closely, rugosely punctured. Base of mandibles aciculated, pilose ; the central part strongly, but not closely, punctured. Thorax closely, somewhat strongly punctured ; the metanotum, if anything, more strongly punctured; the basal area smooth. Abdomen closely, but not so strongly punctured as the thorax; the apices of the segments brownish; the last segment tridentate; the middle tooth large, broad, slightly longer than its width; its apex rounded, projecting roundly, but not much at the sides; the lateral teeth smaller, shorter, broad at the base, narrowed towards the apex, which is rounded. Legs thickly covered with long pale hair; the hair on the tarsi of a brighter fulvous tint.

\section{Gex. ANTHIDIUM, Fab.}

Anthidium capense, sp. nov.

Black; the clypeus, an irregular line on the apex of the sixth and the whole of the apical segments yellow; the apices of the basal five abdominal segments whitish-yellow; the front, vertex, and upper part of thorax thickly covered with long reddish-fulvous hair ; the hair on the face, clypeus, pleuræ, and abdomen white, the hair on the back of the abdomen with a faint fulvous tinge. Wings hyaline, the nervures and stigma black. $\delta$.

Length 9-10 $\mathrm{mm}$; ; breadth $4 \mathrm{~mm}$.

Cape Colony.

Middle of mandibles with a broad yellow band above. Apex of abdomen with four teeth; the outer slightly shorter and broader than the inner. The tarsi, except at the base, and the anterior tibiæ in front are testaceous; middle femora with a short blunt tooth on the apex. Head and thorax closely and strongly punctured. Apex of scutellum bluntly rounded.

The female has the head and mandibles entirely black; the scopa and the hair on the under side of the tarsi rufous; the apical joints of the tarsi ferruginous. The antennæ with bath sexes are entirely black; the basal five bands on the abdomen, in both sexes, are narrow and of uniform width; the last segment, in the female, is entirely black; the calcaria pale. The tooth on the apex of the middle femora is found also in the female. The hind tibiæ narrowed at the base, becoming slightly, gradually wider towards the apex, which is wider than the metatarsus. Tegulæ black. 